\title{
Financial Regulation and Endogenous Macroeconomic Crises
}

\author{
Luca Riccetti $^{1}$, Alberto Russo*2, and Mauro Gallegati ${ }^{2}$ \\ ${ }^{1}$ Sapienza Università di Roma, Roma, Italy \\ ${ }^{2}$ Università Politecnica delle Marche, Ancona, Italy
}

\begin{abstract}
We explore the effects of banking regulation on financial stability and macroeconomic dynamics in an agent-based computational model. In particular, we study the minimum level of capital and the lending concentration towards a single counterpart. We show that an overly tight regulation is dangerous because it reduces credit availability. By contrast, overly loose constraints, associated with a high payout ratio, increase financial fragility that, in turn, damage the real economy. Simulation results support the introduction of regulatory rules aimed at assuring an adequate capitalization of banks, such as the Capital Conservation Buffer (Basel III reform).
\end{abstract}

Keywords: financial regulation, business cycle, leverage, crisis, computational macroeconomics. JEL classification codes: C63, E32, G01, G28.

Acknowledgments: We are grateful for helpful comments and useful suggestions to participants in the "2nd Macro Banking and Finance Workshop" (organized at Università degli Studi di Roma "Tor Vergata", September $18-19^{\text {th }}$ 2014), to participants in the IWcee14 - "International Workshop on Computational Economics and Econometrics" (Roma, June 26 - 27 $7^{\text {th }}$ 2014), to participants in the "XXI International Conference on Money, Banking and Finance" (organized at Luiss Università Guido Carli, Roma, December $10-11^{t h} 2012$, where an earlier version of the paper was presented), and to Maria Giovanna Siena. Authors acknowledge the financial support from the European Community Seventh Framework Programme (FP7) under Socio-economic Sciences and Humanities, grant agreement no.FP7-ICT-255987 (FOC-II), grant agreement no. FP7-ICT-611875 (SYMPHONY), and Sapienza Università di Roma for the research project on Agent based models for representing the interaction between the real economy and finance. Last but not least, we would like to thank two anonymous referees for constructive critics and valuable suggestions. The usual disclaimer applies.

*Department of Management, Università Politecnica delle Marche, Piazzale Martelli 8, 60121 Ancona (Italy). E-mail: alberto.russo@univpm.it 


\section{Introduction}

In this paper we explore the effects of banking regulation on financial and macroeconomic dynamics, using the agent-based decentralized matching macroeconomic model proposed in Riccetti et al. (2015), according to which the macroeconomy is a complex system populated by many heterogeneous agents (households, firms and banks) which directly interact in different markets (goods, labor, credit, and bank deposits), and two policy makers, that is the government and the central bank. In this context, aggregate regularities emerge from the "bottom up" (Epstein and Axtell, 1996) as statistical properties at the meso and macro levels that derive from individual behavioral rules and interaction mechanisms which describe the working of markets (Tesfatsion and Judd, 2006; LeBaron and Tesfatsion, 2008). Therefore, there are at least three main aspects that distinguish our alternative approach compared to mainstream macroeconomics based on DSGE modeling:

- agents follow adaptive rules that can allow them to reach their purposes (consumption, profits, etc.) in spite of their bounded rationality (Simon, 1957) and the presence of limited and asymmetric information; this means that results could be sub-optimal, that is agents are not able to maximize an intertemporal objective function under some constraints. Behavioral and experimental economics support the idea that agents are not fully rational, thus showing a tendency to behave according to relatively simple rules under uncertain information;

- agents are heterogeneous and interact directly (that is, not only indirectly through the price system). The interaction among a multitude of heterogeneous agents leads to complex dynamics as emergent properties: aggregate regularities are obtained by simply summing up individual behaviors. In such a context there is no room for the "representative agent" (Kirman, 1992). Moreover, the economy can experiment a continuous process of disequilibrium, even if the decentralized interaction can endogenously lead to a coordination around a "statistical equilibrium", without exogenously imposing a market clearing condition. However, even in situations of macroeconomic "equilibrium", individuals can be unsatisfied because they are not able to reach the desired choices: for instance, a worker can be involuntary unemployed, a firm can be credit rationed and so on. All in all, this is an alternative microfoundation of macroeconomics, based on the idea that macro is different from micro;

- in a macroeconomic framework with heterogeneous interacting agents crisis can emerge endogenously without the need of an external aggregate shock. Moreover, even a small idiosyncratic shock can cause a large crisis due to network contagion. The presence of a network is a very relevant characteristic and agent-based modeling allows us to analyze its endogenous formation ${ }^{1}$. For instance, the bankruptcy of a firm has an impact on the lending banks that, in turn, face non-performing loans; depending on banks' financial 
soundness, the shock can be absorbed or it can result in banking failures with consequent credit crunch and so on, generating a cascade effect. Therefore, as alreay explained, the interaction can lead to aggregate non-linear complex dynamics of the economic system.

Many papers in the field of agent based computational economics have investigated the role of interaction in a heterogeneous agents setting, exploring the properties of a methodological alternative to neoclassical Walrasian microfoundation, based on the Representative Agent (RA) hypothesis (for a comprehensive review, see Fagiolo and Roventini, 2009, 2012). In Riccetti et al. (2015), a large literature review reports examples of agent-based models showing emergent macroeconomic features based on the interplay between the two fundamental characteristics, heterogeneity and interaction, of agent-based models, providing a discussion from early contributions in the field of microsimulation (Orcutt, 1957, Bergmann, 1974, and Eliasson, 1977).

In particular, Riccetti et al. (2015) developed a model with decentralized interactions, along the lines already traced in the literature (for instance, Fagiolo et al., 2004, Delli Gatti et al., 2005, 2009, 2010, Russo et al., 2007, Gaffeo et al., 2008). Nevertheless, a peculiar aspect of the model developed in Riccetti et al. (2015) is that the decentralized matching process presents common features across markets. This framework has many useful characteristics among which: (i) it fulfills stock-flow consistency as many models also in the mainstream field, (ii) it endogenously creates business cycles in which real and financial aspects interact, (iii) it is well suited to perform computational experiments about policy interventions.

- Stock-flow consistency is a very important feature (see Godley and Lavoie, 2006) that economists are applying also in the field of agent-based macroeconomics as, for instance, in Cincotti et al. (2010, 2012a), Kinsella et al. (2011), Dawid et al. (2012), Seppecher $(2012)^{2}$

- The recent financial turmoil has stressed the importance of the relationship between financial factors and the real economy on the business cycle. It means that models should catch the possibility of firm and bank defaults (financial contagion) and the fundamental role of leverage cycles in shaping the macroeconomic dynamics.

- As for the leverage cycle, many recent contributions try to understand the leverage process both for firms and banks: Adrian and Shin (2008, 2009, 2010), Brunnermeier and Pedersen (2009), Flannery (1994), Fostel and Geanakoplos (2008), Geanakoplos (2010), Greenlaw, Hatzius, Kashyap and Shin (2008), He, Khang and Krishnamurthy (2010), Kalemli-Ozcan et al. (2011). Many of these papers find that the leverage pattern for financial firms (especially investment banks and large commercial banks) is procyclical. The behavior of the leverage level is a component of a more general discussion on firm and bank capital structure, such as in 
Booth et al. (2001), Diamond and Rajan (2000), Gropp and Heider (2010), Lemmon, Roberts and Zender (2008), Rajan and Zingales (1995). The vast majority of agent-based models uses the "pecking order" theory (Donaldson, 1961; Myers and Majluf, 1984) for the capital structure of firms, according to which, when information is asymmetric, investments are financed first by internal funds, then by debt (if internal funds are not enough), and equity is a last resort. A different perspective on the firms' financial structure is represented by the "trade-off" theory, firstly proposed in a paper concerning asset substitution (Jensen and Meckling, 1976), and in a work on underinvestment (Myers, 1977). This theory is based on the trade-off between the costs and benefits of debt and implies that firms select a target debt-equity ratio. Indeed, Graham and Harvey (2001) conduct a survey where $81 \%$ of firms affirm to consider a target debt ratio or range when making their debt decisions. However, the empirical literature finds contrasting evidence to support these (and other) theories. Then, a refined version of the trade-off theory was proposed: the "dynamic trade-off theory". In this theory firms actively pursue target debt ratios even though market frictions temper the speed of adjustment: for instance see Morellec et al. (2012) and Strebulaev and Whited (2012). In other words, firms have long-run leverage targets, but they do not immediately reach them, instead they adjust to the target in some periods. Dynamic trade-off seems to be able to overcome some puzzles related to the other theories, explaining the stylized facts emerged from the empirical analysis. Indeed, numerous papers conclude that it dominates alternative hypotheses: see, for instance, Hovakimian et al. (2001), Graham and Harvey (2001), Mehotra et al. (2003), Flannery and Rangan (2006), Frank and Goyal (2008, 2015). In this paper we use the model of Riccetti et al. (2015), in which firms' capital structure is based on the Dynamic Trade-Off theory $^{3}$, that is firms have a desired ratio between debt and net worth, and they try to reach it by following an adaptive rule governing credit demand. The Dynamic Trade-Off theory has a relevant role in influencing the leverage cycle, with a strong impact on macroeconomic evolution. For this reason, Riccetti et al.(2015) analyze in detail the dynamics of financial variables, firms' leverage and banks' exposure, and their interplay with the business cycle.

- As for financial contagion, a firm's bankruptcy creates losses ("bad debt") for banks that, in turn, have a net worth reduction that can cause a reduction of the credit availability, with further consequences on firms. Moreover, banks could even default in presence of a high bad debt level (especially in the case of a fragile financial system) and this leads to depositors' losses that reduce the aggregate demand (and thus the firms' profitability), besides the credit crunch. In addition, defaulted firms and banks are replaced by new ones that need net worth as initial endowment, which is taken by households' wealth, therefore further reducing the 
aggregate demand.

- The last feature of the model, fundamental for this paper, is the possibility to perform some computational experiments about regulatory issues. In general, agent-based models are often a useful tool for analyzing policy interventions, also considering the interplay of coexisting regulatory rules. For instance, some recent contributions have proposed an analysis of economic policy issues: Dawid et al. (2012) proposes a largescale stock-flow consistent model for economic policy analysis; Delli Gatti et al. (2005) and Cincotti et al. (2010, 2012a) study the role of monetary policy; ${ }^{4}$ Babutsidze (2012) analyzes the implications for monetary policy of price-setting; ${ }^{5}$ Salle et al. (2013) investigates the properties of inflation targeting; van der Hoog and Dawid (2015) explore the formation of bubbles and the following crises along the financial cycle; Russo et al. (2007) analyze the fiscal policy and its effect on R\&D dynamics; the combination of Keynesian management of aggregate demand and Schumpeterian policies aimed at promoting technological progress is studied by Dosi et al. (2010), while Dosi et al. (2012) consider the interplay between income distribution and economic policies; Haber (2008) investigates the effects of fiscal and monetary policies; Neugart (2008) examines labor market policies; Westerhoff and Dieci (2006) and Mannaro et al. (2008) analyze the effects of introducing a Tobin-like tax; Westerhoff (2008) analyzes the role of regulatory policies on financial markets, and Westerhoff and Franke (2012) analyze the effectiveness of various stabilization policies; the agent-based approach has been recently extended to the analysis of climate change policies in an evolutionary macroeconomic framework by Rengs et al. (2015). Hence, agent-based models represent an alternative formulation of microfoundation suited for a complex macroeconomic system; following this different approach may have important implications for policy advice (Dawid and Neugart, 2011). For a comprehensive review, see Fagiolo and Roventini (2009, 2012). Recently, also the debate on banking regulation was faced by agent-based models, as in Neuberger and Rissi (2012) who find (similarly to us) that both unregulated financial systems and overly restrictive regulations have destabilizing effects, or as in Cincotti et al. (2012b) and in Krug et al. (2015); moreover, da Silva and Lima (2015) studies the interplay between the interest rate setting by the central bank and financial regulation.

With the present paper we add some results to the analysis of policy issues in an agent based macroeconomic framework. Summarizing our finding, we show that: (i) for banking stability, the portfolio composition seems to be more relevant than the overall exposure, even if both features are very important; (ii) an overly tight regulation is dangerous because it reduces credit availability; $^{6}$ (iii) overly loose constraints could help banks to make money and to increase their net worth, thus making the constraints not binding, but if bank profits are associated with a higher payout ratio (as really happened in the last 20 years), then financial fragility increases causing a weaker economic environment (higher mean unemployment rate), 
a more volatile business cycle, and a higher probability of triggering crises. These results are related to more general findings that stress two difficulties in determining the "right" policy intervention: (i) a non-linear relationship between the health of the economy and regulation; (ii) the interaction of regulatory rules among themselves and with agents' behavior. Many different models underestimate these complexities. In particular, about the first issue (that is the non-linear relationships between the health of the economy and the regulation), before the "subprime/Lehman Brothers" financial crisis, most of the researchers support the idea that a more developed financial system is associated with a higher growth rate (see, for instance, Levine, 2005). These papers sometimes argue for a favorable view of the liberalization process as well as the regulatory easing that involved the financial sector (for instance, Aghion at al., 2010, state: "tighter credit constraints also induce procyclicality in the growth rate of the economy", "they also reduce the mean growth rate of the economy", "these results mean that financial frictions contribute to both lower mean growth and higher volatility"), and of the globalization process (see, for instance, Kose at al., 2009). However, after the last financial crisis and the sovereign debt crisis, many authors challenge this idea: some authors stress the trade-off between growth and stability, others show that a stable financial system can even have a positive impact on growth (Sinha, 2012) ${ }^{7}$. Moreover, some papers highlight the presence of non-linear relationships, supporting the findings of our research. Indeed, Cecchetti and Kharroubi (2012) find that "the level of financial development is good only up to a point, after which it becomes a drag on growth" and, above all, the Global Financial Stability Report published by the International Monetary Fund in October 2012, using a Panel Estimation with Quadratic Term over the period 1998-2010, shows the non-linear relationship between financial regulation and economic outcomes, stating at page 161 that: "Some features that improve the resilience of a financial system can adversely interact with economic outcomes once they exceed a certain threshold. Capital and liquidity buffers are a case in point. While these financial buffers generally tend to help economic outcomes, the analysis found that beyond certain (fairly high) levels in low-income and emerging market economies, they may be associated with lower economic growth, higher volatility of economic growth, and higher financial stress. This result is generally in line with findings of the Basel Committee on Banking Supervision (BCBS, 2010) on the diminishing benefits of buffers. A similar result has also been found in other studies for the influence of credit-to-GDP ratio on economic volatility". Therefore, the Global Financial Stability Report suggests, as policy implication, the usefulness of Basel III reforms, but if the thresholds do not exceed certain levels. Regarding the second issue above mentioned, a very few papers highlight the importance of considering the interaction effects among rules and banks' behaviour: Vives (2014) shows that optimal levels of capital and liquidity requirements are not independent among themselves, as well as with respect to both the level of disclosure in the market and the level of competition that banks face. The working paper n.28 of the Basel Committee on Banking Supervision (January 2015) underlines the importance of the interplay among accounting rules, prudential regulation 
and bank behavior, showing that the interaction between prudential filters and accounting standards "may generate behavioural responses that warrant further research".

The methodology used to address the financial regulation issue is to perform two sensitivity analyses on two parameters of the model of Riccetti et al. (2015), that constrain the banking activity: the overall credit exposure and the lending concentration towards a single counterpart. Moreover, we analyze what happens if both parameters are changed jointly, calling this case the "deregulation" one. We slightly modify the cited agent-based model to allow banks to extend a higher dividend, to address the fact that, in the last decades, the financial sector obtains a deregulation process coupled with a growing payout policy. For a brief literature review and discussion on the payout policy, see Subsection 4.3.

With our finding we try to give a contribution to the discussion on the Basel III reforms of the banking sector. Indeed, the overall credit exposure is related to the First Pillar of the reform on Capital requirements, in which there are many rules concerning this topic. We now report the ones that are more directly related with our paper:

- the common equity has to be larger than the $4.5 \%$ of risk-weighted assets;

- besides the already mentioned $4.5 \%$, there is an additional $2.5 \%$ of equity (for an overall value of $7 \%$ ) called Capital Conservation Buffer; constraints on a bank's payout and other discretionary distributions are imposed if the common equity falls below this $7 \%$;

- a maximum for the non-risk-based Leverage Ratio (including off-balance sheet exposures) is set in order to avoid overly large leverage ratio based on risk-based measures. The equity has to be above $3 \%$ of total assets value (thus bank's leverage ratio has to be below about 33).

In particular, the Capital Conservation Buffer is also related to our discussion on the payout policy. About the possible implications related to the introduction of the Leverage Ratio see, for instance, Elliott (2009, 2010), Hellwig (2010), Kiema e Jokivuolle (2010).

Instead, the analysis on the lending concentration parameter is associated with the debate on the Second Pillar, about "Risk management and supervision", which also contains the topic of managing risk concentrations.

In general, in recent years, numerous studies have analyzed in detail the various regulatory reforms (or reform proposals) and their impacts both on the economy and on profitability and management of banks, deriving from the strengthening of capital requirements (Jokipii and Milne, 2008; Hanson et al., 2010; King, 2010; Al-Darwish et al., 2011; Carlson et al., 2011; Gambacorta, 2011; Agenor and Pereira da Silva, 2012; Allen et al., 2012; Francis and Osborne, 2012; Mora and Logan, 2012; Tutino et al., 2012; Vollmer and Wiese, 2013; Zhou, 2013). ${ }^{8}$ However, as already said, an important aspect of our contribution is based on the use of the agent-based methodology that allows us to simulate the joint impact of more than a single regulatory rule on macroeconomic performance and financial stability. 
Obviously, our contribution is in any case restricted to some aspects of the Basel III reform, given that this reform concerns a much larger number of aspects, such as the liquidity regulation, the regulation of systemically important financial institutions (SIFIs), the pro-cyclicality of the capital requirements (with the Countercyclical buffer) and so on (for a clear summary table of the whole Basel III reforms, see: www.bis.org/bcbs/basel3/b3summarytable.pdf).

The paper is organized as follows. Section 2 presents the model setup and, in particular, Subsection 2.1 reports the characteristics of the four markets (credit, labor, goods, and bank deposits) which composes our economy; the evolution of agents' wealth is described in subsection 2.2, while the behavior of policy makers is discussed in subsection 2.3. Section 3 summarizes the model's dynamics and the simulation results found in the baseline setting of the model reported in Riccetti et al. (2015). We provide the regulatory analyses in Section 4, in which we perform sensitivity and Monte Carlo experiments, comparing these findings with the baseline model outputs and highlighting the implications for financial regulation. Section 5 concludes.

\section{The model}

This paper, as already explained, is based on the model reported in Riccetti et al. (2015). Our economy evolves over a time span $t=1,2, \ldots, T$ and is composed by households ( $h=$ $1,2, \ldots, H)$, firms $(f=1,2, \ldots, F)$, banks $(b=1,2, \ldots, B)$, a central bank, and the government. Agents are boundedly rational and live in an incomplete and asymmetric information context, thus they follow simple rules of behavior and use adaptive expectations.

Agents interact in four markets: (i) credit market; (ii) labor market; (iii) goods market; (iv) deposit market. The interaction between the demand (firms in the credit and labor markets, households in the goods market, and banks in the deposit market) and the supply (banks in the credit market, households in the labor and deposit markets, and firms in the goods market) sides of the four markets follows a common decentralized matching protocol, even if each agent in the demand side observes a list of potential counterparts in the supply side and chooses the most suitable partner according to some market-specific criteria. In particular, interaction develops in the following way: a random list of agents in the demand side is set, then the first agent in the list observes a random subset of potential partners, whose size depends on a parameter $0<\chi \leq 1$ (which proxies the degree of imperfect information), and chooses the cheapest one. After that, the second agent on the list performs the same activity on a new random subset of the updated potential partner list. The process iterates till the end of the demand side list. Subsequently, a new random list of agents in the demand side is set and the whole matching mechanism continues until either one side of the market (demand or supply) is empty or no further matchings are feasible because the highest bid (for example, the money till available to the richest firm) is lower than the lowest ask (for example, the lowest wage asked by till unemployed workers). 
The sequence of events which occurs in the different markets is fully described in Appendix A.

Now, we briefly explain the main features of the four markets. However, for a detailed description of agents' behavioral rules, see Appendix B.

\subsection{Markets}

\subsubsection{Credit market}

In each period, firms and banks at first interact in the credit market. Firm's $f$ credit demand at time $t$ depends on its net worth $A_{f t}$ and the leverage target $l_{f t}$. Hence, required credit is:

$$
B_{f t}^{d}=A_{f t} \cdot l_{f t}
$$

The evolution of the leverage target changes according to expected profits and inventories: if expected profits are above expected interest rate and there are few inventories, the firm enlarges its target leverage, and vice versa (for details, see Equation 10 in Appendix B).

Banks set their credit supply $B_{b t}^{d}$ depending on their net worth $A_{b t}$, deposits $D_{b t}$, and the quantity of money provided by the central bank $m_{b t}$. However, we add some regulatory constraints:

$$
B_{b t}^{d}=\min \left(\hat{k}_{b t}, \bar{k}_{b t}\right)
$$

where $\hat{k}_{b t}=\gamma_{1} \cdot A_{b t}, \bar{k}_{b t}=\gamma_{2} \cdot A_{b t}+D_{b t-1}+m_{b t}$, with parameters $\gamma_{1}>1$ and $0 \leq \gamma_{2} \leq$ 1. Parameter $\gamma_{1}$ represents the maximum exposure in risky assets (corporate lending) as a multiple of bank capital. Instead, parameter $\gamma_{2}$ represents the maximum percentage of capital that can be invested, therefore $\bar{k}_{b t}$ constraints the bank to lend no more than the sum of its deposits, the money received by the central bank and a part of its equity 9 .

Moreover, in order to reduce risk concentration, only a fraction $0<\beta \leq 1$ of the total amount of the credit $B_{b t}^{d}$ can be lent to a single firm.

Bank $b$ charges an interest rate on the firm $f$ at time $t$ according to the following equation:

$$
i_{b f t}=i_{C B}+\hat{i}_{b t}+\bar{i}_{f t}
$$

where $i_{C B}$ is the nominal interest rate set by the central bank, $\hat{i}_{b t}$ is a bank-specific component (see Equation 11 in Appendix B), and $\bar{i}_{f t}=\rho^{l_{f t}} / 100$ is a firm-specific component, that is a risk premium on firm target leverage $l_{f t}$ (with parameter $\rho>0$ ).

The bank-specific component decreases if the bank did not manage to lend all the credit supply to firms and increases in the opposite case (for details, see Equation 11 in Appendix B). Indeed, at the end of the interaction mechanism, each firm ends up with a credit $B_{f t} \leq B_{f t}^{d}$ and each bank lends firms an amount $B_{b t} \leq B_{b t}^{d}$. The difference between desired and effective credit is equal to $B_{f t}^{d}-B_{f t}=\hat{B}_{f t}$ and $B_{b t}^{d}-B_{b t}=\hat{B}_{b t}$, for firms and banks respectively. 
Moreover, we hypothesize that banks ask for an investment in risk free government securities equal to $P D_{b t}^{d}=\bar{k}_{b t}-B_{b t}$. Given our simplifying setting, this allows banks to recover the cost of the interests paid on deposits and central bank money that banks do not lend. If the sum of desired government bonds exceeds the amount of outstanding public debt then the effective investment $P D_{b t}$ is proportionally rescaled. Instead, if public debt exceeds the banks' desired amount, then the central bank buys the difference.

\subsubsection{Labor market}

Government, firms and households interact in the labor market. On the demand side, first of all, the government hires a fraction $g$ of households. The remaining part is available for working in the firms. Firm's $f$ labor demand depends on available funds, that is net worth and bank credit: $A_{f t}+B_{f t}$. In other words, for instance a firm that realized high profits at time $t-1$ is very likely to enlarge both its net worth (with reinvested profits) and its banks' credit (higher leverage as explained in the previous subsection) in order to expand its production, hiring a larger number of workers.

On the supply side each worker posts a wage $w_{h t}$ which increases if he/she was employed in the previous period and vice versa. Moreover, the required wage has a minimum related to the price of a good (for details, see Equation 12 in Appendix B).

As a result of the decentralized matching between labor supply and demand, each firm ends up with a number of workers $n_{f t}$ and a residual cash (insufficient to hire an additional worker) and a fraction of households may remain unemployed. The wage of unemployed people is set equal to zero.

\subsubsection{Goods market}

Subsequently, households and firms interact in the goods market. On the demand side, households set the desired consumption on the basis of their disposable income and wealth (for details, see Equation 13 in Appendix B).

Firms produce consumption goods on the basis of hired workers as follows:

$$
y_{f t}=\phi \cdot n_{f t}
$$

where $\phi \geq 1$ is a productivity parameter. They put in the goods market their current period production and previous period inventories $\hat{y}_{f t-1}$. The selling price increases if in the previous period the firm managed to sell all the output, while it reduces if it had positive inventories. Moreover, the minimum price at which the firm wants to sell its output is set so that it is at least equal to the average cost of production, that is ex-ante profits are at worst equal to zero (for details, see Equation 14 in Appendix B).

As a consequence of the interaction between the supply and demand sides in the goods market, each household ends up with residual cash, which is not enough to buy an additional good 
and which it will try to deposit in a bank. At the same time, firms may remain with unsold goods (inventories), that they will try to sell in the next period.

\subsubsection{Deposit market}

Banks and households interact in the deposit market. Banks represent the demand side and households are on the supply side. Banks offer an interest rate on deposits according to their funds' requirement: if a bank exhausts the credit supply by lending to private firms or government then it decides to increase the interest rate paid on deposits, so as to attract new depositors, and vice versa. However, the interest rate on deposits has an upper bound given by the policy rate $i_{C B}$; this represents both the rate at which banks could refinance from the central bank and the rate paid by the government on public bonds (for details, see Equation 15 in Appendix B).

Households determine their savings to be deposited in banks as the desired savings plus the residual cash at the end of the interaction in the consumption market. Moreover, they set the minimum interest rate they want to obtain on bank deposits as follows: a household that in the previous period found a bank paying an interest rate higher or equal to the desired one decides to ask for a higher remuneration. In the opposite case, it did not find a bank satisfying its requirements, thus it kept its money in cash and now asks for a lower rate for details, see Equation 16 in Appendix B). We hypothesize that a household deposits all the available money in a single bank that offers an adequate interest rate.

\subsection{Profits, dividends and wealth dynamics}

\subsubsection{Firms}

At the end of the interaction in the credit, labor and goods markets, every firm $f$ calculates its profit/loss:

$$
\pi_{f t}=p_{f t} \cdot \bar{y}_{f t}-W_{f t}-I_{f t}
$$

where $p_{f t}$ is the price set by the firm $f$ on its goods, $\bar{y}_{f t}$ are the sold goods, $W_{f t}$ is the sum of wages paid to employed workers, and $I_{f t}$ is the sum of interests paid on bank loans. Firms pay a proportional tax $\tau$ on positive profits; however, firms can subtract previous negative profits in the calculation of the tax base. After taxes, we indicate net profits with $\bar{\pi}_{f t}$.

Finally, firms pay a percentage $\delta_{f t}$ as dividends on positive net profits. The fraction $0 \leq \delta_{f t} \leq$ 1 goes down if in the previous period the firm produces and sells all the goods (no inventories), then wants to retain a larger share of profits to enlarge production, and vice versa.

Thus, the evolution of firm $f$ 's net worth is given by the previous period net worth plus profit net of taxes and dividends. 
If $A_{f t} \leq 0$ then the firm goes bankrupt and a new entrant replaces the bankrupted agent according to a one-to-one replacement. Banks linked to defaulted firms lose a fraction of their loans, but recover the remaining part; analytically, $\left(A_{f t}+B_{f t}\right) / B_{f t}$ is the recovery rate.

The new entrant starts with an initial net worth equal to a multiple of the average goods price and the money needed to finance entrants is subtracted from households' wealth. We set to one the leverage of the new firm. Moreover, the entrant sets an initial price for its goods equal to the mean price of survival firms.

\subsubsection{Banks}

As a result of interaction in the credit and the deposit markets, the bank b's profit is equal to:

$$
\pi_{b t}=i n t_{b t}+i_{t}^{\Gamma} \cdot \Gamma_{b t}-i_{b t-1}^{D} \cdot D_{b t-1}-i_{C B} \cdot m_{b t}-b a d_{b t}
$$

where $i n t_{b t}$ represents the interests gained by bank $b$ on lending to non-defaulted firms, $i_{t}^{\Gamma}$ is the interest rate on government securities $\Gamma_{b t}, i_{b t-1}^{D}$ is the interest rate paid on the sum of deposits $D_{b t-1}, i_{C B}$ is the interest rate paid on the amount of money $m_{b t}$ required to the Central Bank, and badbt is the amount of "bad debt" due to bankrupted firms. Bad debt is the loss given default of the loans to bankrupted firms, that is a fraction 1 less the recovery rate (see the previous subsection) of the loans.

Banks pay a proportional tax $\tau$ on positive profits; however, they subtract previous negative profits in the calculation of the tax base. We indicate net profits with $\bar{\pi}_{b t}$.

Finally, banks pay a percentage $\hat{\delta_{b t}}$ as dividends on positive net profits. The fraction $0 \leq$ $\hat{\delta_{b t}} \leq 1$ evolves according to the following rule, which is different from the one used in Riccetti et al. (2015), because here we add the parameter $0 \leq \bar{\delta}_{b} \leq 1$ :

$$
\hat{\delta_{b t}}=\overline{\delta_{b}}+\delta_{b t}
$$

where:

$$
\delta_{b t}= \begin{cases}\delta_{b t-1} \cdot(1-\alpha \cdot U(0,1)), & \text { if } \quad B_{b t}>0 \text { and } \hat{B}_{b t}=0 \\ \delta_{b t-1} \cdot(1+\alpha \cdot U(0,1)), & \text { if } \quad B_{b t}=0 \text { or } \hat{B}_{b t}>0\end{cases}
$$

That is, if the bank does not manage to lend the desired supply of credit then it decides to distribute more dividends (because it does not need high reinvested profits), and vice versa.

Thus, the evolution of bank b's net worth is given by the previous period net worth plus profit net of taxes and dividends.

If $A_{b t} \leq 0$ then the bank is in default and a new entrant takes its place. Households linked to defaulted banks lose a fraction of their deposits (the loss given default rate is calculated as $\left.1-\left(A_{b t}+D_{b t}\right) / D_{b t}\right)$. The initial net worth of the new entrant is a multiple of the average goods price. Moreover, the initial bank-specific component of the interest rate $\left(\hat{i}_{b t}\right)$ is equal to the mean value across banks. 


\subsubsection{Households}

According to the operations in the labor, goods, and deposit markets, the household $h$ 's wealth evolves as follows:

$$
A_{h t}=\left(1-\tau^{\prime}\right) \cdot\left[A_{h t-1}+(1-\tau) \cdot w_{h t}+d i v_{h t}+i n t_{h t}^{D}-c_{h t}\right]
$$

where $\tau^{\prime}$ is the tax rate on wealth (applied only on wealth exceeding a threshold $\overline{\tau^{\prime}} \cdot \bar{p}$, which is a multiple of the average goods price), $\tau$ is the tax rate on income, $w_{h t}$ is the wage gained by employed workers, div $v_{h t}$ is the fraction (proportional to the household $h$ 's wealth compared to overall households' wealth) of dividends distributed by firms and banks net of the amount of resources needed to finance new entrants (hence, this value may be negative), $i n t_{h t}^{D}$ represents interests on deposits, and $c_{h t}$ is the effective consumption. Households linked to defaulted banks lose a fraction of their deposits as already explained.

\subsection{Government and central bank}

Government's current expenditure is given by the sum of wages paid to public workers $\left(G_{t}\right)$ and the interests paid on public debt to banks. Moreover, government collects taxes on incomes and wealth and receives interests gained by the central bank. The difference between expenditures and revenues is the public deficit $\Psi_{t}$. Consequently, public debt is $\Gamma_{t}=\Gamma_{t-1}+\Psi_{t}$. The presence of the government as an acyclical sector is a very important feature of the model. Indeed, hiring public workers, the government provides a fraction of the aggregate demand. In this way it partially stabilizes the economy by reducing output volatility.

Central bank decides the policy rate $i_{C B}$ and the quantity of money to put into the system in accordance with the interest rate ${ }^{10}$. In order to do that, the central bank observes the aggregate excess supply or demand in the credit market and sets an amount of money $M_{t}$ to reduce the gap in the subsequent period of time.

\section{Baseline model results}

We explore the dynamics of the model by means of computer simulations. The parameter setting is reported in Table 2 which is in Appendix C. With this setting we perform two Monte Carlo analyses with two different time spans. The first analysis exploits 1000 Monte Carlo simulations over a "short" time horizon of 150 periods, of which we examine the results for the last 50, because the first 100 periods are used to initialize the model. The second study regards 100 Monte Carlo simulations over a "long" time span of 500 periods (again, the first 100 are used to initialize the model). However, this model analyzes the business cycle, then it performs a short/medium run analysis, given that we do not consider the features that characterize the long run growth (tied to the productivity of both capital and labor). So, the 
"long" time horizon simulation is only another way to assess the business cycle fluctuations, able to show some additional features of the computational model.

In 995 out of 1000 of the "short" simulations and in 98 out of 100 of the "long" Monte Carlo simulations, we observe the emergence of endogenous business cycles with the following pattern: an increase of firms' profits determines an expansion of production and, if banks extend the required credit, this effect could be amplified resulting in more employment; the fall of the unemployment rate increases wage inflation that, on the one hand, expands the aggregate demand, while on the other hand reduces firms' profits, possibly causing the inversion of the business cycle. Then, we can notice that the engine of the economy is given by the dynamic relationship between unemployment and profit rate, enlarged by a financial accelerator mechanism. The "real" mechanism is that an increase of profits boosts the expansion of the economy and then a fall of the unemployment rate follows; low unemployment increases wages, so firms try to save on production costs reducing labor demand. This results in a rise of unemployment that lowers the profit rate in the subsequent period due to a lack of aggregate demand. However, the presence of unemployed people decreases wages and this makes firms hire a larger number of workers, thus boosting the beginning of a new expansionary phase of the business cycle.

Firms' leverage and banks' exposure are the financial drivers that enlarge business fluctuations: growing firms ask for more credit to expand the production; subsequently, low unemployment fosters wages that, together with the rise of interest payments on the increased debt, reduces firms' profitability. Thus, the business cycle reverses and financial factors amplify the recession, indeed the relatively low level of profits with respect to interest payments induces a deleveraging process. According to empirical evidence (for example, Kalemli-Ozcan et al., 2011), there is a negative but modest correlation between firms' leverage and the unemployment rate, while there is a more significant negative correlation between banks' exposure and unemployment. The importance of banks' capitalization is evident because this variable determines the credit conditions, thus influencing firms' leverage and the macroeconomic evolution.

Focusing on the financial sector, the model shows that a more leveraged financial sector sustains the expansion of the economy, but the relationship is non-linear: for low levels, an increase of bank exposure reduces the rate of unemployment; instead, for high levels of bank exposure a further increase makes unemployment higher. In other words, if banks increase their exposure enlarging credit to firms, the latter hire more workers and the unemployment rate decreases. But, when the exposure of banks becomes "excessive" this leads to instability (more failures) and an increase of the unemployment rate follows.

Business fluctuations are mitigated by the government, representing an acyclical sector, that plays a central role in reducing the output volatility through stabilizing the aggregate demand. However, in 5 out of 1000 "short" simulations and in 2 out of 100 "long" ones, the system is characterized by large and extended crises, that is the average unemployment 
rate reaches values above 20\%. Differently from the usual business cycle mechanism, wage reduction due to growing unemployment does not reverse the cycle, but generates a lack of aggregate demand that amplifies the recession in a vicious circle for which the fall of purchasing power prevents firms from selling commodities, then firms decrease production, unemployment continues to rise, and the recession further deteriorates.

For details on the average values of macroeconomic variables analyzed in the Monte Carlo simulations, see Table 3 in Appendix C.

\section{Regulation analysis}

In this section we perform some computational experiments to assess the effects of modifying the regulatory constraints on bank activities. For this analysis, we change the parameters $\gamma_{1}$ and $\beta$ (see Section 2.1.1).Thus, we try to address in a stylized way some banking regulation topics. Indeed, we can only implement some aspects of the Basel III proposals in this simplified framework given that, for instance, banks do not use various instruments (that is, on the asset side they only lend to firms and residually to the government, while on the passive side they only have equity and deposits) and there are no different lending and borrowing horizons in order to assess liquidity vs. solvency problems. However, as already explained in Section 1, studying the role of parameter $\gamma_{1}$ we can analyze the banking capital and leverage regulation, given that this parameter constrains the risky assets over the bank's net worth ${ }^{11}$. Instead, studying parameter $\beta$ we can address the maximum lending concentration issue, which is included in the Second Pillar ("Risk management and supervision") of Basel III Capital regulation.

In the baseline model we set $\gamma_{1}=10$ and $\beta=0.1$. We now discuss the experimental settings of the additional analyses we propose; then, we will report the results in the Subsections below.

The first analysis is on parameter $\beta .^{12}$ In particular, we perform 1000 replications of the model over a time span of $T=150$ organized as follows: 20 simulations for each value of $\beta$ from $1 \%$ to $50 \%$ with step $1 \%$, keeping all the other parameters unchanged. Then, we analyze the impact of parameter $\beta$ over the "long" time horizon. That is, we run 100 Monte Carlo repetitions with $T=500$ for $\beta=0.50$, in order to compare these results with those emerging from the 100 simulations of the baseline model over the "long" time span.

The second analysis is on parameter $\gamma_{1}$. As in the previous case, we perform both a sensitivity analysis over a time span of $T=150$ changing $\gamma_{1}$ from 1 to 50 with 50 steps of 1 (again, for each step we perform 20 simulations for an overall amount of 1000 simulations) and a study with 100 Monte Carlo repetitions on the "long" time span $T=500$ with $\gamma_{1}=50$.

The third analysis concerns both parameters at the same time, that is we study a parameter setting with $\gamma_{1}=50$ and $\beta=0.5$ with 100 Monte Carlo simulations on the "long" time horizon $T=500$. In this way we assess a case of wide financial "deregulation". 
Last, we perform two batteries of 100 Monte Carlo repetitions where $\bar{\delta}_{b}=0.45$, and the other parameters are set either as in the baseline model setting $\left(\gamma_{1}=10\right.$ and $\left.\beta=0.1\right)$ or as in the "deregulation" case $\left(\gamma_{1}=50\right.$ and $\left.\beta=0.5\right)$; this analysis is performed over the "long" horizon. In this way we analyze the "deregulation" case in a high payout ratio environment. The discussion on banking payout is strictly related with the Basel III Capital Conservation Buffer, because a constraint on banks discretionary distributions is imposed if the common equity falls below this threshold.

The statistics regarding the unemployment rate and its volatility in the various scenarios, with $T=500$, are reported in Table 1 . For additional statistics regarding other central variables, see Table 4 and 5 in Appendix D.

\subsection{Sensitivity analysis on parameter $\beta$}

We perform the sensitivity analysis on parameter $\beta$ that constrains the maximum lending concentration. Firstly, as already said, we run 1000 simulations on the "short" time horizon for 50 different values of $\beta$, from 0.01 to 0.50 with 0.01 step.

Figure 1 shows that when $\beta$ is very small, that is if banking regulation is excessively tight, there is a relevant credit rationing which causes many firm defaults and high rates of unemployment, even though banks are safe and their default is very unlikely. As the parameter grows, while remaining low, the credit mismatch reduces or disappears, followed by a reduction of firm defaults and unemployment. Further increasing $\beta$, the riskiness of the financial system tends to rise, as shown by the growing number of bank defaults. This induces at first a slight increase of the mean rate of unemployment. Then, when the regulatory constraint becomes too loose, system's financial fragility is excessive and this can lead to large bankruptcy avalanches of firms and banks. As a consequence, banks' net worth collapses resulting in a strong credit constraint. At the same time, firms are not able to hire workers because their net worth also decreases and they do not receive enough credit from the banking system. Hence, the credit crunch results in a large unemployment rate. Moreover, this determines high unemployment volatility and a growing number of large crises (average unemployment rate above 20\%): for instance, when $\beta=0.05$ the mean unemployment rate is $8.7 \%$ and there are no large crises, while if $\beta=0.50$ it becomes $18.73 \%$ with a large crisis scenario in 6 out of 20 simulations ${ }^{13}$.

To further check for the robustness of these results and for the presence of large crises, we repeat the Monte Carlo simulations over a "long" time horizon $T=500$ (as usual, excluding from the analysis the first 100 time steps used to initialize the economy). We compare the findings obtained when $\beta=0.5$, with those of the baseline case, that is $\beta=0.1$ (see Table 1). If $\beta=0.5$, we observe 22 out of 100 simulations with large crises, a much higher number than the 2 simulations when $\beta=0.1$. Moreover, if we consider all simulations in which the unemployment rate exceeds $20 \%$ for at least one period, we calculate 36 cases when $\beta=0.5$ versus the 3 cases when $\beta=0.1$. The riskiness of this setting is confirmed by the 
Figure 1: Sensitivity analysis on the impact of the parameter $\beta$ - from 0.01 to 0.50 with step 0.01 - on the following variables: (i) unemployment rate, (ii) firms default rate, (iii) banks default rate, (iv) credit mismatch (that is the difference between the money available from banks and not lent and the money required by firms and not received). All values are the average on the 20 simulations with the corresponding $\beta$ value.
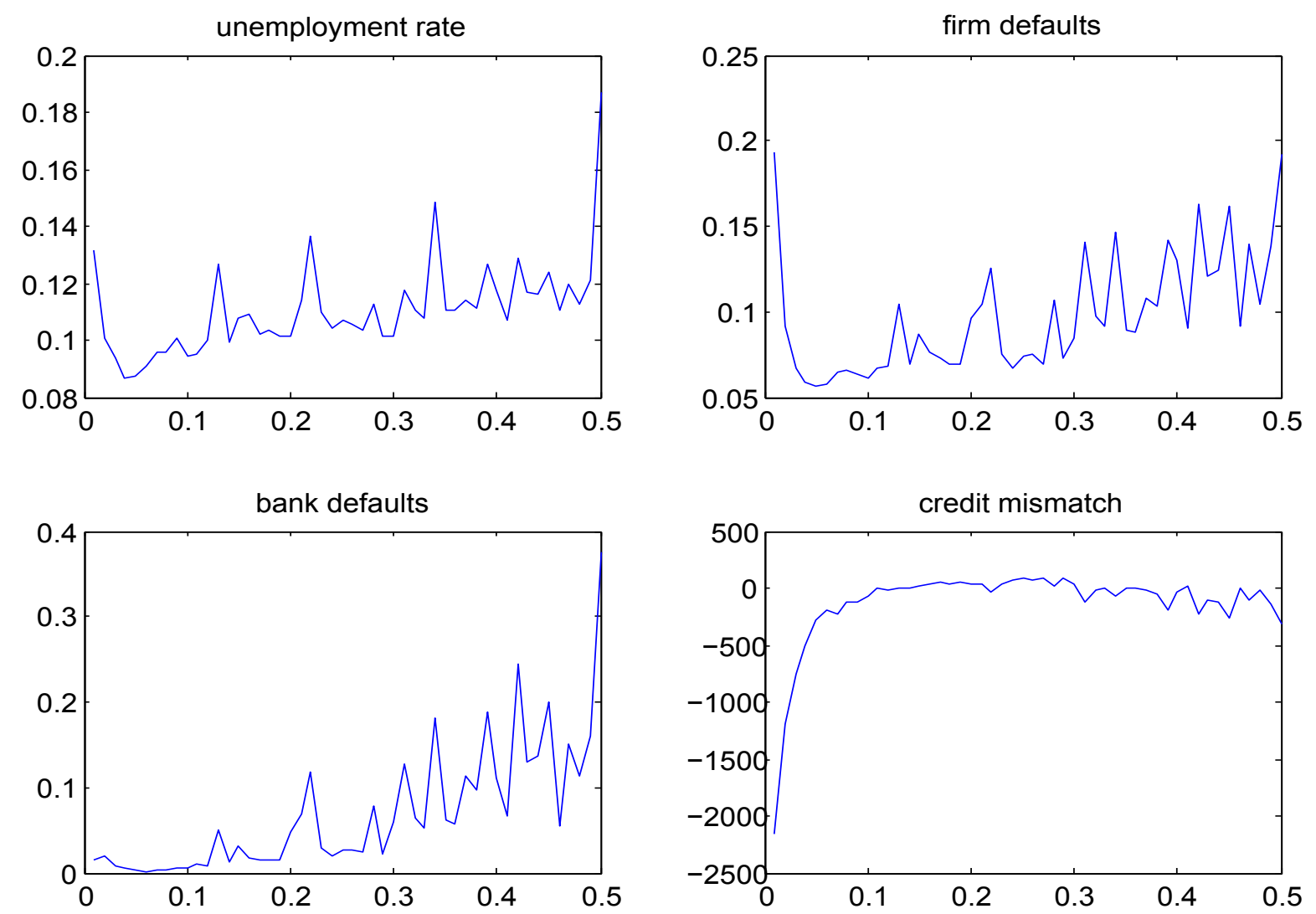
fact that, even focusing on the simulations in which the average unemployment rate is below $20 \%$, the mean unemployment rate is greater (10.61\% vs $9.73 \%$, statistically different at $1 \%$ level) and the unemployment volatility is higher (1.99\% vs $1.84 \%$, statistically different at $1 \%$ level). In other words, compared to the baseline setting, the main difference when $\beta=0.5$ is the significantly higher frequency of large and extended crises; moreover, the level and the volatility of the unemployment rate is a bit higher even if we discard the large crisis cases (and this is also one of the reasons for which large crises are more probable).

\subsection{Sensitivity analysis on parameter $\gamma_{1}$}

Now we study parameter $\gamma_{1}$ that represents the maximum bank exposure in risky assets (corporate lending) as a multiple of bank capital. As in the previous Section, we run 1000 simulations on the "short" time horizon for 50 different values of $\gamma_{1}$, from 1 to 50 with step of 1 . With $1 \leq \gamma_{1} \leq 3$, firms face a huge credit constraint that causes a very high number of firm defaults. A high unemployment rate follows. Instead, differently from the analysis on $\beta$, we do not detect significant changes from $\gamma_{1}=4$ to $\gamma_{1}=50$, that is a loose banking regulation does not increase the risk of financial crises (see Figure 2). However, we see that banks do not always use their maximum possible exposure (reaching very high amounts of risky assets compared to their net worth), given that this is only a theoretical upper bound. Indeed, in this paper banks do not allocate their portfolio considering a risk-return optimization, therefore we can not assess the issue of different banking strategies in presence of different regulatory rules.

Nevertheless, to better check for the presence of large crises, also in this case we repeat the Monte Carlo simulations over a "long" time horizon $T=500$. We compare the case when $\gamma_{1}=50$ to the baseline case of $\gamma_{1}=10$ (see Table 1 ). With a longer time span, the risk of financial crises emerges: if $\gamma_{1}=50$, we count 12 simulations with large crises, versus the 2 simulations of the baseline case. Considering all simulations in which the unemployment rate exceeds $20 \%$ for at least one period, we calculate 15 cases when $\gamma_{1}=50$ against 3 cases when $\gamma_{1}=10$. Excluding the large crisis simulations, the mean unemployment rate is quite low (9.08\% vs $9.73 \%$, statistically different at $1 \%$ level), but the possibility to expand the risky assets volume takes to a higher business cycle volatility (unemployment volatility equal to $2.09 \%$ vs $1.84 \%$ in the baseline setting; the two average volatilities are statistically different at $1 \%$ level), that can also trigger large crises.

To sum up, an excessively tight constraint on $\gamma_{1}$ seems to be more dangerous than an overly loose one, but also a very high value of $\gamma_{1}$ is harmful, given that it increases the possibility of triggering financial crises.

Comparing these results with those on maximum lending concentration $\beta$, we note that the portfolio composition seems to be more relevant than the overall exposure, even if both features are very important for banking stability. This statement could support the thesis 
Figure 2: Sensitivity analysis on the impact of the parameter $\gamma_{1}-$ from 1 to 50 with step 1 on the following variables: (i) unemployment rate, (ii) firms default rate, (iii) banks default rate, (iv) credit mismatch (that is the difference between the money available from banks and not lent and the money required by firms and not received). All values are the average on the 20 simulations with the corresponding $\gamma_{1}$ value.
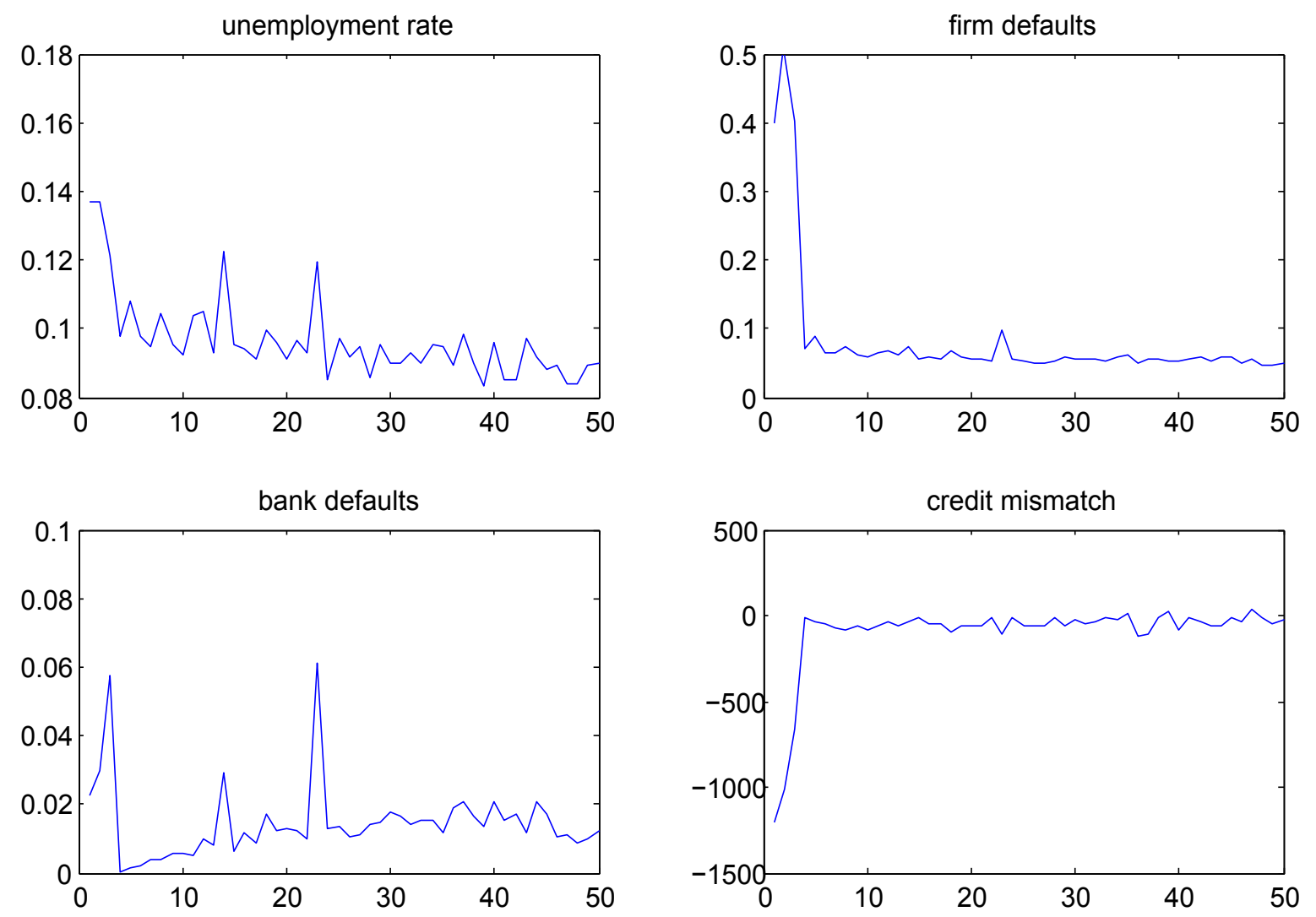
of many academicians and practitioners that encourage a return from the prudential to the structural regulation approach (for instance a sort of separation between investment and commercial banking activities). However, the debate about a banking structural reform was more intense immediately after the bankruptcy of Lehman Brothers, when designated commissions produced some regulations or proposals: first of all the so called "Volcker Rule" inside the "DoddFrank Wall Street Reform and Consumer Protection Act" in the US, but also reports such as the "Vickers Report" for the United Kingdom and the "Liikanen Report" for the European Union.

\subsection{Deregulation case}

We analyze the case of a very loose constraint on both parameters, $\beta$ and $\gamma_{1}$, calling it banking "deregulation" case. In practice, we perform 100 Monte Carlo simulations over the "long" time horizon $(T=500)$ fixing $\beta=0.5$ and $\gamma_{1}=50$; in this case banks can lend firms an amount of money up to 50 times the net worth and they could even give half this amount to a single firm. This is an overly risky regulation. However, we detect only one simulation with a large crisis and this is also the only case in which the unemployment rate goes beyond $20 \%$. In the other 99 simulations, the mean unemployment rate is $9.29 \%$ and it never exceeds $20 \%$.

The reason is quite simple: banks make a huge amount of money, they become relatively large compared to the overall economic size and, in particular, to firms' size, then they are able to provide all the required credit without approaching the constraints. For instance, over the 99 simulations without a large crisis, the mean ratio between lent credit and banks' net worth is below 4 , even if the limit is 50 .

But what happens if the large amount of profits, that banks are able to obtain in the deregulation case, are used to enrich the payout ratio ${ }^{14}$ of banks and not to enlarge banks' net worth? DeAngelo et al. (2004) and Denis and Osobov (2008) show that most profitable firms increase their dividends and, more in general, there is ample literature on financialization (for example, see Stockhammer, 2004) and on corporate governance trend of maximizing shareholder value (for instance, see Lazonick and O'Sullivan, 2000, who argue a shift in management strategies from "retain and invest" to "downsize and distribute" in the USA). Focusing on banks, in particular, various studies observe an increase of banks payout ratio in the last decades: Acharya et al. (2011) show the dividend amount for 10 US and 11 European large banks from 2000 to 2008, while Brogi (2010) exhibits the dividends distributed by Italian banks; for instance, the Italian banking system distributed 1.4 Euro billions (payout ratio of $27.46 \%$ ) in 1990, while it distributed 14.4 Euro billions (payout ratio of $64.43 \%$ ) in 2006, with an increase of both net profits and payout ratio. Brogi (2010) says: "In the period 2004-2007, immediately preceding the crisis, the Italian banking system benefited from a considerable rise in profitability (...), but it did not seize the opportunity to strengthen capital base and, on the contrary, limited allocations to reserves and opted instead for generous payout policies". 
Moreover, these authors (but also the Basel Committee on Banking Supervision) highlight that even when the financial crisis started and the banking system suffered the depletion of common equity through losses, banks continued to pay dividends. Indeed, banks are reluctant to reduce dividends, also because high dividend payments signal to the market the soundness of the bank. Acharya et al. (2011) explain that dividends were paid to equity holders at the expense of the debt holders (including the taxpayers who fund bailouts) (...) the inertia in bank accounting makes even a distressed bank appear healthy in terms of its book capital ratios, enabling a transfer in violation of priority of debt over equity ${ }^{15}$. Brogi (2010) shows that from 2001 to 2010 new shares of Italian listed banks totaled about a third of aggregate dividends paid by the system in the same period, then an early imposition of dividend distribution constraint is an important reform needed by the regulatory system. E.S. Rosengren, President \& Chief Executive Officer of the Federal Reserve Bank of Boston, expresses a similar opinion at "Rethinking Central Banking" Conference held in Washington D.C. in October 2010. This debate makes the Basel Committee introduce the so-called "Capital Conservation Buffer", explained in Section 1: if the Common Equity of a bank goes below the $7 \%$ threshold, the bank will have a distribution constraint ${ }^{16}$. Moreover, in Europe, the Single Supervisory Mechanism (SSM) gives the supervision on large bank groups to the European Central Bank (ECB), and the ECB performs a comprehensive assessment (information recruiting, asset quality review and stress tests), after which it imposes constraints on dividends, issue of new shares and sale of non-core assets to low capitalized banks.

In light of the reported stylized facts and of the regulatory debate, we modify the parameter $\bar{\delta}_{b}$ from zero to 0.45 . With this value we perform 100 Monte Carlo repetitions two times with the baseline setting for $\gamma_{1}$ and $\beta\left(\gamma_{1}=10\right.$ and $\left.\beta=0.1\right)$ and in the deregulation setting $\left(\gamma_{1}=50\right.$ and $\left.\beta=0.5\right)$. In this way we analyze the case of full "deregulation" in a high payout ratio environment.

When $\gamma_{1}=10$ and $\beta=0.1$, as reported in Table 1 , the number of large crisis simulations is equal to 2 as in the baseline case. However, the number of simulations in which the unemployment rate exceeds $20 \%$ increases to 12 . This is coherent with the higher mean unemployment rate (now $11.28 \%$, statistically different at $1 \%$ level). It is obviously due to the lower accumulation of bank's net worth which reduces the credit supply, while it increases financial fragility (tied to an increased bank leverage).

Instead, now, "deregulation" worsens the economic environment: the number of large crisis simulation is equal again to 2 , but the number of simulations in which the unemployment rate exceeds $20 \%$ is 45 , the mean unemployment rate grows to $12.33 \%$, and the mean unemployment volatility grows to $2.55 \%$ (both the unemployment rate and the unemployment volatility are statistically different at $1 \%$ from the baseline scenario values). Deregulation causes a high business cycle volatility and it implies two features: on one hand it often happens to reach very high unemployment levels during strong cyclical downturns, on the other hand regulatory flexibility helps the system not to remain trapped in the large crisis scenario, 
that is, it is easier for the system to recover from large unemployment ${ }^{17}$.

To conclude: if deregulation is preparatory and associated with a growth of banks' net worth, it strengthens the banking sector, making the same rules not binding. Instead, if deregulation is tied to higher payout and not to a higher net worth, then the leverage and the credit risk really increase, causing a more fragile economy (higher mean unemployment rate) and a more volatile business cycle.

Table 1: Summary of Monte Carlo simulations. In each row there is a parameter combination for which we perform 100 Monte Carlo repetitions on a time span of $T=500$. We report: (i) the number of simulations in which the mean unemployment rate is above $20 \%$ ( $\mathrm{N}^{\circ}$ large crisis), (ii) the number of simulations in which the maximum unemployment rate is above $20 \%$ (Max U > 20\%), (iii) the mean unemployment rate in the non large crisis simulations (Mean U \%, standard deviation in brackets), (iv) the mean unemployment standard deviation in the non large crisis simulations (U volatility \%, standard deviation in brackets).

\begin{tabular}{l|cccc}
\hline & $\mathrm{N}^{\circ}$ large crisis & Max U $>20 \%$ & Mean U \% & U volatility $\%$ \\
\hline$\beta=0.1, \gamma_{1}=10, \bar{\delta}_{b}=0$ & 2 & 3 & $9.73(0.87)$ & $1.84(0.12)$ \\
$\beta=0.5, \gamma_{1}=10, \bar{\delta}_{b}=0$ & 22 & 36 & $10.61(2.08)$ & $1.99(0.31)$ \\
$\beta=0.1, \gamma_{1}=50, \bar{\delta}_{b}=0$ & 12 & 15 & $9.08(1.50)$ & $2.09(0.95)$ \\
$\beta=0.5, \gamma_{1}=50, \bar{\delta}_{b}=0$ & 1 & 1 & $9.29(0.13)$ & $2.04(0.12)$ \\
$\beta=0.1, \gamma_{1}=10, \bar{\delta}_{b}=0.45$ & 2 & 12 & $11.28(0.92)$ & $1.96(0.99)$ \\
$\beta=0.5, \gamma_{1}=50, \bar{\delta}_{b}=0.45$ & 2 & 45 & $12.33(3.02)$ & $2.55(2.08)$ \\
\hline \hline
\end{tabular}

\section{Concluding remarks}

We present an agent-based macroeconomic model that allowed us to investigate the role of financial regulation on macroeconomic dynamics.

The model is populated by heterogeneous agents (households, firms and banks) that interact according to a fully decentralized matching mechanism. The matching protocol is common to all markets (goods, labor, credit, deposits) and represents a best partner choice in a context of imperfect information. Firms' financial structure is based on a dynamic target leverage. The model is useful because it gives rise to emergent macroeconomic properties like the fluctuation of the unemployment rate, the relevance of leverage cycles and credit constraints on economic performance, the presence of bank defaults and the role of financial instability, and so on. In particular, simulations show that endogenous business cycles emerge as a consequence of the interaction between real and financial factors: when firms' profits are improving, they try to expand the production and, if banks extend the required credit, this results in more employment; the decrease of the unemployment rate leads to the rise of wages which, on the one hand, increases the aggregate demand, while on the other hand reduces firms' profits, 
and this may cause the inversion of the business cycle. Moreover, model simulations highlight that even extended crises can endogenously emerge with a strong reduction of real wages, a consequent fall of the aggregate demand that, in turn, induces firms to decrease production, so enlarging the unemployment rate, in a vicious positive feedback circle. In these cases, the system may remain trapped, without the possibility of spontaneously recovering unless an exogenous intervention occurs.

This modeling framework is useful to understand the effects of certain policy or institutional changes. In this paper we perform some computational experiments on the role of the parameter governing banks' capital regulation and credit portfolio concentration. The first constraint is related to the First Pillar of Basel III Capital regulation, while the credit concentration is tied to the Second Pillar.

The analysis shows that:

- if banking regulation is excessively tight then strong credit constraints emerge, deteriorating economic and financial conditions;

- if regulatory rules are overly loose, then an excessive financial risk follows and this may result in bankruptcy avalanches of both firms and banks and large unemployment. This is strongly relevant when regulation allows for high risk concentration;

- portfolio composition seems to be more relevant than the overall exposure, even if both features are very important for banking stability;

- if "deregulation" is associated with a growth of banks' net worth, it strengthens the banking sector, making the regulatory constraints not binding. However, this result is tied to a banks' profit reinvestment in net worth larger than that observed during the last 20 years, when banks did not retain the huge amount of profit made and then took all the possible risk amount allowed;

- if deregulation is tied to higher payout and not to a higher net worth, then the leverage and the credit risk really increase, causing a more fragile economy (higher mean unemployment rate and a more volatile business cycle). This supports the introduction of the Basel III Capital Conservation Buffer.

Moreover, our policy experiments also give some interesting and more general results:

- we find non-linear relationships between the health of the economy (proxied by the unemployment rate) and the parameter values;

- the interaction of regulatory rules could give rise to complex outputs producing unexpected results, such as the good performance of the economy when deregulation is associated with "low" dividends; 
- implications are strictly related with other behavioral assumptions of the model (for instance the already mentioned willingness to distribute profits);

- to determine the "right" intervention, policy makers should not underestimate these complexities.

To further develop the analysis we will work on a large research agenda:

- work on other policy experiments (for instance on fiscal and monetary policies);

- test the consequences of alternative assumptions, such as labor market rigidity, heterogeneous consumption/saving behavior, etc.;

- refine the model with a varying number of actors (firms and banks) during the business cycle and a diversity of decisional timings (and frequency) in the different markets;

- extend the model by introducing new markets, for instance the stock and bond markets, the interbank market, and a market for investment goods;

- extend the model with long-run growth factors (heterogeneous workers'skills, R\&D investments, etc.);

Obviously, these items are strictly related. When we will extend the model, we will also be able to test for further alternative assumptions and different parameter settings (based on an empirical calibration of the the model), and then we will assess more detailed policy experiments. For instance, the presence of investment goods is strictly related to technological progress underlying economic growth, or the presence of stock, bond and interbank markets will allow us to investigate the impact of agents' portfolio allocation based on a more complicated behavior for financial choices. 


\section{Notes}

${ }^{1}$ In general terms, the dynamics of any contagion process crucially depends on network topology. In this context, heterogeneity becomes of paramount importance: some nodes may be too big or too connected to fail. Since Allen and Gale (2000), a relevant literature strand contributes to analyze how some topological aspects can reduce contagion and systemic risk. For instance, Allen and Gale (2000) highlight the benefits of increasing diversification, suggesting that a more connected network is better for financial stability, while later works (such as Gai and Kapadia, 2010, or Battiston et al., 2012) have challenged this view, showing that diversification is not always beneficial for stability, and underlining instead the systemic risk caused by default cascades and other contagion effects

${ }^{2}$ For a comprehensive description of a large-scale agent-based macroeconomic model, including a detailed explanation of the initialization phase within a stock-flow consistent structure, see the Eurace@Unibi User Guide by Dawid et al. (2011).

${ }^{3}$ This capital structure is also investigated in the agent-based model proposed by Riccetti et al. (2013a).

${ }^{4}$ Ashraf et al. (2014) analyze the impact of the trend rate of inflation on macroeconomic performance.

${ }^{5}$ This paper is included in a book edited by Gaffard and Napoletano (2012) in which there are many contributions on agent-based models and economic policy.

${ }^{6}$ For a different view on the role of bank capital requirements in reducing credit availability, see Admati and Hellwig (2013a,b).

${ }^{7}$ Other authors point out various related issues: for instance, Broner and Ventura (2013) show that financial liberalization might lead to different outcomes from "large capital inflows and higher investment and growth" to "volatile capital flows and unstable domestic financial markets" or to "domestic capital flight"; instead, Moral-Benito and Roehn (2014) evidence the relationship between two of the potential causes of the crisis, that is global imbalances and financial market deregulation, showing that financial market regulations affect current account balances and that different aspects of these regulations can have opposing effects on the current account).

${ }^{8}$ There is ample literature on this topic from academicians, policy makers and practitioners, which has led to lively debates and interesting conferences. Just to make an example, see the BIS Paper Number 60 entitled "Macroprudential regulation and policy", which is the proceedings of a joint conference organized by the BIS and the Bank of Korea in Seoul on 17-18 January 2011.

${ }^{9} \mathrm{~A}$ numerical example can clarify the meaning of these rules: suppose bank 1 to have equity $A_{1}=10$, deposits $D_{1}=30$ and money from the central bank $M_{1}=20$. Using the baseline setting of the parameters, that is $\gamma_{1}=10$ and $\gamma_{2}=0.5$, the bank presents $\hat{k}_{1}=10 * 10=100$, but it cannot lend 100 to firms because it has only $\bar{k}_{1}=0.5 * 10+30+20=55$, therefore the maximum amount that can be lent is 55 . Instead, suppose bank 2 to have equity $A_{2}=10$, deposits $D_{2}=100$ and money from the central bank $M_{2}=20$. In this case bank 2 presents $\hat{k}_{2}=10 * 10=100$, and it can lend all the 100 to firms because it has $\bar{k}_{2}=0.5 * 10+100+20=125$.

${ }^{10}$ The mechanism is similar to "liquidity injections" implemented in de Walque et al. (2010). Although we keep unchanged the interest rate while the quantity of money varies to adjust the credit mismatch between firms and banks, the reported results are not strictly dependent on this assumption. Indeed, we also perform some computational experiments involving two types of Taylor rules for interest rate setting: the first one resembling the working of the Fed (equal weight for inflation and output gap) and the second one similar to the ECB behavior (only inflation targeting). For a detailed discussion, see Riccetti et al. (2013b).

${ }^{11}$ This parameter does not exactly correspond either to the $4.5 \%$ minimum capital requirement or to the $3 \%$ Leverage Ratio rule, because we consider that the risk comes only from the credit extended to firms, thus implying that risk-free government bonds have a risk-weighting equal to zero (because the Central Bank is committed to buying the unsold government bonds, without a spread over the policy rate).

${ }^{12}$ In a sense, given that we set 80 firms in our computational experiments, each entity can approximately 
represent one of the 99 "divisions" of the ISIC rev.4 (International Standard Industrial Classification of All Economic Activities) or the 70 "industries" of the GICS (Global Industry Classification Standard). For instance if $\beta=0.1$, this implies that each bank can have a maximum exposition towards each "division" equal to $10 \%$ of the total supply of credit.

${ }^{13}$ Given the quite high number of simulations involved in this sensitivity analysis, we avoid to perform a larger number of repetitions that would be useful to smooth the patterns shown in the figure. In spite of the spikes in the plots, we think that the tendencies of the four variables are understandable.

${ }^{14}$ Here we proxy the payout ratio with the percentage of dividends paid on profits, even if now repurchases are the dominant form of payout (see Brav et al., 2005, or Skinner, 2008).

${ }^{15}$ Admati and Hellwig (2013b), facing the market discipline problem, also point out the conflicts of interest between debt and equity holders: "The extensive use of debt in banking actually creates significant conflicts of interest between bank managers and bank shareholders on the one hand, and creditors or taxpayers on the other".

${ }^{16}$ This regulatory debate goes with the debate on the proper notion of regulatory capital, see for instance Acharya et al. (2011). Indeed, the Tier 2 notion used by the Basel II agreement, that is, a buffer against depositors loss then including hybrid claims such as preferred equity or subordinated debt, makes the composition of bank capital change from equity to hybrid claims, increasing banking leverage relative to common equity. Moreover, the injections of bank capital from Governments, for instance through the TARP program in the United States, often took the form of preferred equity rather than common equity, further increasing leverage and not reducing the reluctance of banks to extend credit.

${ }^{17}$ For this reason, the idea of a countercyclical regulation, tighter during the expansionary phases and looser during recessions, such as the Basel III "Countercyclical Buffer" (that is, authorities can ask up to an additional $2.5 \%$ of common equity when credit grows too much), could be an important tool. 


\section{References}

[1] Acharya V.V., Gujral I., Kulkarni N. and H.S. Shin (2011) Dividends and Bank Capital in the Financial Crisis of 2007-2009. NBER Working Paper 16896.

[2] Admati A.R. and M.F. Hellwig (2013a) The Bankers' New Clothes: What's Wrong with Banking and What to Do about It. Princeton, NJ: Princeton University Press.

[3] Admati A.R. and M.F. Hellwig (2013b) Does debt discipline bankers? An academic myth about bank indebtedness. INET Research Note 24, Institute for New Economic Thinking (February).

[4] Adrian T. and H.S. Shin (2008) Liquidity, monetary policy and financial cycles. Current Issues in Economics and Finance 14(1), Federal Reserve Bank of New York (January/February).

[5] Adrian T. and H.S. Shin (2009) Money, liquidity, and monetary policy. American Economic Review 99(2), 600-605.

[6] Adrian T. and H.S. Shin (2010), Liquidity and leverage. Journal of Financial Intermediation 19(3), 418-437.

[7] Agénor P.R. and L.A. Pereira da Silva (2012) Cyclical effects of bank capital requirements with imperfect credit markets. Journal of Financial Stability 8(1), 43-56.

[8] Aghion P., Angeletos G.M., Banerjee A. and K. Manova (2010) Volatility and growth: credit constraints and the composition of investment. Journal of Monetary Economics 57(3), 246-265.

[9] Al-Darwish A., Hafeman M., Impavido G., Kemp M. and P. O’Malley (2011) Possible unintended consequences of Basel III and solvency II. IMF Working Papers 11/187.

[10] Allen B., Chan K.K., Milne A. and S. Thomas (2012) Basel III: is the cure worse than the disease? International Review of Financial Analysis 25(C), 159-166.

[11] Allen F. and D. Gale D. (2000) Financial contagion Journal of Political Economy 108(1), 1-33.

[12] Ashraf Q., Gershman B. and P. Howitt (2014) How inflation affects macroeconomic performance: an agent-based computational investigation. Macroeconomic Dynamics, doi: $10.1017 /$ S1365100514000303

[13] Basel Committee on Banking Supervision (2015) The interplay of accounting and regulation and its impact on bank behaviour: literature review. Working Paper 28 (January).

[14] Babutsidze Z. (2012) Asymmetric (s,s) pricing: implications for monetary policy. Revue de l'OFCE 124, 177-204.

[15] Battiston S., Delli Gatti D., Gallegati M., Greenwald B.C. and J.E. Stiglitz (2012) Liaisons dangereuses: increasing connectivity, risk sharing, and systemic risk. Journal of Economic Dynamics \& Control 36(8), 1121-1141. 
[16] BCBS (2015) The interplay of accounting and regulation and its impact on bank behaviour: literature review. Working Paper 28 (January), Basel Committee on Banking Supervision.

[17] Bergmann B.R. (1974) A microsimulation of the macroeconomy with explicitely represented money flows. Annals of Economic and Social Measurement 3, 475-489.

[18] Booth L., Asli Demirgu-Kunt V.A. and V. Maksimovic (2001) Capital structures in developing countries. Journal of Finance 56(1), 87-130.

[19] Brav A., Graham J.R., Harvey C.R. and R. Michaely (2005) Payout policy in the 21st century. Journal of Financial Economics 77, 483-527.

[20] Brogi M. (2010) Capital adequacy and dividend policy: evidence from Italian banks. In G. Bracchi and D. Masciandaro (eds.), Le banche italiane sono speciali?, XV Rapporto annuale della Fondazione Rosselli, available at SSRN: http://ssrn.com/abstract=1707962.

[21] Broner F.A. and J. Ventura (2013) Rethinking the effects of financial liberalization. Working Paper, Universitat Pompeu Fabra.

[22] Brunnermeier M.K. and L.H. Pedersen (2009) Market liquidity and funding liquidity. Review of Financial Studies 22(6), 2201-2238.

[23] Carlson M., Shan H. and M. Warusawitharana (2011) Capital ratios and bank lending: a matched bank approach. Finance and Economics Discussion Series 2011-34, Board of Governors of the Federal Reserve System.

[24] Cecchetti S.G. and Kharroubi (2012) Reassessing the impact of finance on growth. BIS Working Papers 381.

[25] Cincotti S., Raberto M. and A. Teglio (2010) Credit money and macroeconomic instability in the agent-based model and simulator Eurace. Economics - The Open-Access, Open-Assessment E-Journal, 4(26).

[26] Cincotti S., Raberto M. and Teglio (2012a) Debt deleveraging and business cycles. An agentbased perspective. Economics - The Open-Access, Open-Assessment E-Journal, 6(27).

[27] Cincotti S., Raberto M. and Teglio (2012b) Macroprudential policies in an agent-based artificial economy. Revue de l'OFCE 124, 205-234.

[28] Da Silva, M.A. and G.T. Lima (2015) Combining monetary policy and financial regulation: an agent-based modeling approach. Working Paper 394, Banco Central do Brasil.

[29] Dawid H., Gemkow S., Harting P., van der Hoog S. and M. Neugart (2011) Eurace@Unibi Model User Manual.

[30] Dawid H., Gemkow S., Harting P., van der Hoog S. and M. Neugart (2012). The Eurace@Unibi model: an agent-based macroeconomic model for economic policy analysis. Working Papers in Economics and Management 05-2015, University of Bielefeld. 
[31] Dawid H., Gemkow S., Harting P., van der Hoog S. and M. Neugart (2015) Agent-based macroeconomic modeling and policy analysis: the Eurace@Unibi model. In Chen S.-H. and M. Kaboudan (eds.), Handbook on Computational Economics and Finance, Oxford University Press.

[32] Dawid H. and M. Neugart (2011) Agent-based models for economic policy design. Eastern Economic Journal 37(1), 44-50.

[33] DeAngelo H., DeAngelo L. and D.J. Skinner (2004) Are dividends disappearing? Dividend concentration and the consolidation of earnings. Journal of Financial Economics 72, 425-456.

[34] Delli Gatti D., Gaffeo E. and M. Gallegati (2005) The apprentice wizard: monetary policy, complexity and learning. New Mathematics and Natural Computation 1(1), 109-128.

[35] Delli Gatti D., Gallegati M., Greenwald B., Russo A. and J.E. Stiglitz (2009) Business Fluctuations and Bankruptcy Avalanches in an Evolving Network Economy, Journal of Economic Interaction and Coordination 4(2), 195-212.

[36] Delli Gatti D., Gallegati M., Greenwald B., Russo A. and J.E. Stiglitz (2010) The financial accelerator in an evolving credit network. Journal of Economic Dynamics and Control 34(9), $1627-1650$.

[37] Denis D.J. and I. Osobov (2008) Why do firms pay dividends? International evidence on the determinants of dividend policy. Journal of Financial Economics 89, 62-82.

[38] De Walque G., Pierrard O. and A. Rouabah (2010) Financial (in)stability, supervision and liquidity injections: a dynamic general equilibrium approach. The Economic Journal 120, 12341261.

[39] Diamond D.W. and R. Rajan (2000) A theory of bank capital. Journal of Finance 55(6), 24312465.

[40] Donaldson G. (1961) Corporate debt capacity: a study of corporate debt policy and the determination of corporate debt capacity, Harvard Business School, Harvard University.

[41] Dosi G., Fagiolo G. and A. Roventini (2010) Schumpeter meeting Keynes: a policy-friendly model of endogenous growth and business cycles. Journal of Economic Dynamics and Control 34(9), 1748-1767.

[42] Dosi G., Fagiolo G., Napoletano M. and A. Roventini (2012) Income distribution, credit and fiscal policies in an agent-based Keynesian model. LEM Papers Series 2012/03, Sant'Anna School of Advanced Studies.

[43] Eliasson G. (1977) Competition and market processes in a simulation model of the Swedish economy. American Economic Review 67, 277-281. 
[44] Elliott D. (2009) Quantifying the effects on lending of increased capital requirements. Pew Financial Reform Project Briefing Paper 7.

[45] Elliott D. (2010) A further exploration of capital requirements: effects of competition from other financial sectors and effects of size of bank or borrower and of loan type. The Brooking Institution.

[46] Epstein J.M. and R.L. Axtell (1996) Growing Artificial Societies: Social Science from the Bottom Up, MIT Press.

[47] Fagiolo G., Dosi G. and R. Gabriele R. (2004) Matching, bargaining, and wage setting in an evolutionary model of labor market and output dynamics. Advances in Complex Systems 7(2), 157-186.

[48] Fagiolo G. and A. Roventini (2009) On the scientific status of economic policy: a tale of alternative paradigms. The Knowledge Engineering Review 27(Special Issue 02), 163-185.

[49] Fagiolo G. and A. Roventini (2012) Macroeconomic Policy in DSGE and Agent-Based Models. SSRN Workin Paper Series, available at http://ssrn.com/abstract=2011717.

[50] Flannery M.J. (1994) Debt maturity and the deadweight cost of leverage: optimally financing banking firms. American Economic Review 84(1), 320-31.

[51] Flannery M.J. and K.P. Rangan (2006) Partial adjustment toward target capital structures. Journal of Financial Economics 79(3), 469-506.

[52] Fostel A. and J. Geanakoplos (2008) Leverage cycles and the anxious economy. American Economic Review 98(4), 1211-1244.

[53] Frank M.Z. and V.K. Goyal (2008) Tradeoff and pecking order theories of debt. In Espen Eckbo (ed.) The Handbook of Empirical Corporate Finance, pp. 135-197, Elsevier.

[54] Frank M.Z. and V.K. Goyal (2015) The profits-leverage puzzle revisited. Review of Finance 19(4), 1415-1453.

[55] Francis W.B. and M. Osborne (2012) Capital requirements and bank behavior in the UK: are there lessons for international capital standards? Journal of Banking $\mathscr{E}$ Finance 36(3), 803-816.

[56] Gaffard J.-L. and M. Napoletano (2012) Agent-based models and economic policy. Revue de l'OFCE: Debates and Policies.

[57] Gaffeo G., Delli Gatti D., Desiderio S. and M. Gallegati (2008) Adaptive microfoundations for emergent macroeconomics. Eastern Economic Journal 34(4), 441-463.

[58] Gai P. and S. Kapadia (2010) Contagion in financial networks. Proceedings of the Royal Society A: Mathematical, Physical and Engineering Science 466(2120), 2401-2423. 
[59] Gambacorta L. (2011) Do bank capital and liquidity affect real economic activity in the long run? A VECM analysis for the US. Economic Notes 40(3), 75-91.

[60] Geanakoplos J. (2010) Leverage cycle. Cowles Foundation Paper 1304, Yale University.

[61] Godley W. and M. Lavoie (2006) Monetary Economics: An Integrated Approach to Credit, Money, Income, Production and Wealth. Palgrave MacMillan.

[62] Graham J.R. and C. Harvey (2001) The theory and practice of corporate finance. Journal of Financial Economics 60, 187-243.

[63] Greenlaw D., Hatzius J., Kashyap A.K. and H.S. Shin (2008) Leveraged losses: lessons from the mortgage market meltdown. Proceedings of the U.S. Monetary Policy Forum.

[64] Gropp R. and F. Heider (2010) The determinants of bank capital structure. Review of Finance 14(4), 587-622.

[65] Haber G. (2008) Monetary and fiscal policy analysis with an agent-based macroeconomic model. Jahrbücher für Nationalökonomie und Statistik 228, 276-295.

[66] Hanson S., Kashyap A. and J. Stein (2010) An analysis of the impact of substantially heightened capital requirements on large institutions. University of Chicago, Booth School of Business and Harvard University.

[67] He Z., Khang I.G. and A. Krishnamurthy (2010) Balance sheet adjustments in the 2008 crisis. IMF Economic Review 58, 118-156.

[68] Hellwig M. (2010) Capital regulation after the crisis: business as usual? CESifo DICE Report $8(2), 40-46$.

[69] Hovakimian A., Opler T. and S. Titman (2001) The debt-equity choice. Journal of Financial and Quantitative Analysis 36, 1-24.

[70] International Monetary Fund (2012) Global Financial Stability Report (October).

[71] Jensen M.C. and W.H. Meckling (1976) Theory of the firm: managerial behavior, agency costs, and ownership structure. Journal of Financial Economics 3, 305-360.

[72] Jokipii T. and A. Milne (2008) The cyclical behaviour of European bank capital buffers. Journal of Banking \&J Finance 32(8), 1440-1451.

[73] Kalemli-Ozcan S., Sorensen B. and S. Yesiltas (2011) Leverage across firms, banks, and countries. NBER Working Papers 17354.

[74] Kiema I. and E. Jokivuolle (2011) Leverage ratio requirement, credit allocation and bank stability. Bank of Finland Research Discussion Papers, 10. 
[75] King M.R. (2010) Mapping capital and liquidity requirements to bank lending spreads. BIS Working Papers 324.

[76] Kinsella S., Greiff M. and E. Nell (2011) Income distribution in a stock-flow consistent model with education and technological change. Eastern Economic Journal 37(1), 134-149.

[77] Kirman A.P. (1992) Whom or what does the representative individual represent? Journal of Economic Perspectives 6(2), 117-136.

[78] Kose M.A., Prasad E., Rogoff K. and S.J. Wei (2009) Financial globalization: a reappraisal. IMF Staff Papers 56(1).

[79] Krug S., Lengnick M. and H.W. Wohltmann (2015) The impact of Basel III on financial (in)stability - an agent-based credit network approach. Quantitative Finance 15(12), 1917-1932.

[80] Lazonick W. and M. O'Sullivan (2000) Maximising shareholder value: a new ideology for corporate governance. Economy and Society 29(1), 13-35.

[81] LeBaron B. and L.S. Tesfatsion (2008) Modeling macroeconomies as open-ended dynamic systems of interacting agents. American Economic Review 98(2), 246-250.

[82] Lemmon M., Roberts M. and J. Zender (2008) Back to the beginning: persistence and the cross-section of corporate capital structure. Journal of Finance 63, 1575-1608.

[83] Levine R. (2005) Finance and growth: theory and evidence. In Philippe Aghion and Steven N. Durlauf (eds.) Handbook of Economic Growth, Volume 1A, Chapter 12, Elsevier.

[84] Mannaro K., Marchesi M. and A. Setzu (2008) Using an artificial financial market for assessing the impact of Tobin-like transaction taxes. Journal of Economic Behavior and Organization $67,445-462$.

[85] Mehrotra V., Mikkelsen W. and M. Partch (2003) Design of financial policies in corporate spin-offs. Review of Financial Studies 16, 1359-1388.

[86] Mora N. and A. Logan (2012) Shocks to bank capital: evidence from UK banks at home and away. Applied Economics 44(9), 1103-1119.

[87] Moral-Benito E. and O. Roehn (2014) The impact of financial (de)regulation on current account balances. Documentos de Trabajo 1424, Banco de Espana.

[88] Morellec E., Nikolov B. and N. Schurhoff (2012) Corporate governance and capital structure dynamics. Journal of Finance 67, 803-848.

[89] Myers, S.C. (1977) Determinants of corporate borrowing. Journal of Financial Economics 5(2), $147-175$.

[90] Myers S.C. and N.S. Majluf (1984) Corporate financing and investment decisions when firms have information that investors do not have. Journal of Financial Economics 13, 87-224. 
[91] Neuberger D. and R. Rissi (2012) Macroprudential banking regulation: does one size fit all? Thuenen-Series of Applied Economic Theory, University of Rostock.

[92] Neugart M. (2008) Labor market policy evaluation with ACE. Journal of Economic Behavior and Organization 67, 418-430.

[93] Orcutt G.H. (1957) A new type of socio economic system. Review of Economics and Statistics $58,773-797$.

[94] Rajan R. and L. Zingales (1995) What do we know about capital structure? Some evidence from international data. Journal of Finance 50, 1421-1460.

[95] Rengs B., Scholz-Wackerle M., Gazheli A., Antal M. and J. van den Berg (2015) Testing innovation, employment and distributional impacts of climate policy packages in a macroevolutionary systems setting. Working Paper 83, WWWforEurope.

[96] Riccetti L., Russo A. and M. Gallegati (2013a) Leveraged network-based financial accelerator. Journal of Economic Dynamics and Control 37(8), 1626-1640.

[97] Riccetti L., Russo A. and M. Gallegati (2013b) Unemployment benefits and financial leverage in an agent based macroeconomic model. Economics: The Open-Access, Open-Assessment EJournal 7(2013-42), 1-44.

[98] Riccetti L., Russo A. and Gallegati (2015) An agent-based decentralized matching macroeconomic model. Journal of Economic Interaction and Coordination 10(2), 305-332.

[99] Russo A., Catalano M., Gaffeo E., Gallegati M. and M. Napoletano (2007) Industrial dynamics, fiscal policy and R\&D: evidence from a computational experiment. Journal of Economic Behavior and Organization 64(3-4), 426-447.

[100] Salle I., Yildizoglu M. and M.A. Sénégas (2013) Inflation targeting in a learning economy: an ABM perspective. Economic Modelling 34, 114-128.

[101] Seppecher P. (2012) Flexibility of wages and macroeconomic instability in an agent-based computational model with endogenous money. Macroeconomic Dynamics 16(s2), 284-297.

[102] Skinner D.J. (2008) The evolving relation between earnings, dividends, and stock repurchases. Journal of Financial Economics 87, 582-609.

[103] Simon H.A. (1957) Models of Man. New York: Wiley \& Sons.

[104] Sinha A. (2012) Financial sector regulation and implications for growth. BIS Papers 62.

[105] Sinitskaya E. and L.S. Tesfatsion (2015) Macroeconomies as constructively rational games. Journal of Economic Dynamics and Control 61, 152-182.

[106] Stockhammer E. (2004) Financialisation and the slowdown of accumulation. Cambridge Journal of Economics 28(5), 719-741. 
[107] Strebulaev I. A. and T. M. Whited (2012) Dynamic Models and Structural Estimation in Corporate Finance, Boston and Delft: Now Publisher.

[108] Tesfatsion L.S. and K.L. Judd (2006) Handbook of Computational Economics: Agent-Based Computational Economics, Volume II, North-Holland.

[109] Tutino F., Birindelli G. and P. Ferretti (2012) Bank capital and Basel 3 impacts on Italian banks. Corporate Ownership \& Control 10(1), 75-87.

[110] Van der Hoog S. and H. Dawid (2015) Bubbles, crashes and the financial cycle: insights from a stock-flow consistent agent-based macroeconomic model. Working Papers in Economics and Management 1/2015, University of Bielefeld.

[111] Vives X. (2014) Strategic complementarity, fragility, and regulation. Review of Financial Studies 27(12), 3547-3592.

[112] Vollmer U. and H. Wiese (2013) Minimum capital requirements, bank supervision and special resolution schemes. Consequences for bank risk-taking. Journal of Financial Stability 9(4), 487-497.

[113] Westerhoff F. (2008) The use of agent-based financial market models to test the effectiveness of regulatory policies. Jahrbücher für Nationalökonomie und Statistik 228, 195-227.

[114] Westerhoff F. and R. Dieci (2006) The effectiveness of Keynes' Tobin transaction taxes when heterogeneous agents can trade in different markets: a behavioral finance approach. Journal of Economic Dynamics and Control 30, 293-322.

[115] Westerhoff F. and R. Franke (2012) Agent-based models for economic policy design: two illustrative examples. BERG Working Paper 88, University of Bamberg.

[116] Zhou C. (2013) The impact of imposing capital requirements on systemic risk. Journal of Financial Stability 9(3), 320-329. 


\section{APPENDIX A: Sequence of events}

The sequence of events occurring in each period of time runs as follows:

1. At first firms ask for credit to banks given the demand deriving from their net worth and leverage target. In each period, the leverage level changes according to expected profits and inventories.

2. Banks set their credit supply depending on their net worth, deposits and the quantity of money provided by the central bank. Moreover, they must comply with some regulatory constraints.

3. Banks and firms interact in the credit market. At the end of the matching process, some banks may lend all the available credit supply while others may remain with some residual money; similarly, some firms may obtain the required credit while other may remain credit constrained.

4. The government hires public workers.

5. Firms hire workers in the labor market. The labor demand depends on available funds, that is net worth and bank credit. After the labor matching some firms satisfy their labor demand, while others remain with residual cash; at the same time, some people may remain unemployed. Employed people pay income taxes to the government.

6. Firms produce consumption goods on the basis of hired workers. They put in the goods market their current period production and previous period inventories.

7. Individuals decide their desired consumption on the basis of their wages and wealth (net of taxes).

8. Individuals and firms interact in the goods market. As a result, some households satisfy their desired consumption, while others may remain with residual cash; on the other hand, some firms sell all the produced output, while others may accumulate inventories.

9. Individuals determine their savings (that is, programmed saving plus residual cash) to be deposited in banks.

10. Firms calculate profits and survival firms repay their debt to banks, pay taxes, and distribute dividends to households.

11. Banks calculate profits. Individuals lose (part of) deposited money in case of bank defaults. Survival banks pay taxes and distribute dividends to households. 
12. The government collects taxes and, given the wage expenditure for public workers and the interest on outstanding public debt, calculates its deficit (surplus), and updates the overall debt.

13. Banks buy government securities to employ excess liquidity. The central bank purchases the remaining securities.

14. Agents update their wealth, on which they pay capital levy.

15. Central bank decides the amount of money to be lent to banks in the following period according to credit demand/supply unbalance.

16. New entrants replace bankrupted agents (firms or banks with negative net worth) according to a one-to-one replacement. The money needed to finance new entrants is subtracted from households' wealth. In the case private wealth is not enough, then government intervenes. Therefore, the model is stock flow consistent given that we do not create new financial resources when new entrants substitute defaulted agents.

The simulation code of the agent-based model, written in the $R$-project software, is available as an on-line appendix to the present paper. 


\section{APPENDIX B: Details on behavioral rules}

In this appendix we provide additional details on the agents' behavioral rules that we avoided to insert in the main text in order to have a concise discussion. For the sake of clarity, we follow the same order as in the main text, that is we present behavioral rules regarding the action of agents in the following markets: credit, labor, goods, and deposits.

Credit market. The leverage target is set according to the following rule:

$$
l_{f t}= \begin{cases}l_{f t-1} \cdot(1+\alpha \cdot U(0,1)), & \text { if } \pi_{f t-1} /\left(A_{f t-1}+B_{f t-1}\right)>i_{f t-1} \text { and } \hat{y}_{f t-1}<\psi \cdot y_{f t-1} \\ l_{f t-1}, & \text { if } \pi_{f t-1} /\left(A_{f t-1}+B_{f t-1}\right)=i_{f t-1} \text { and } \hat{y}_{f t-1}<\psi \cdot y_{f t-1} \\ l_{f t-1} \cdot(1-\alpha \cdot U(0,1)), & \text { if } \pi_{f t-1} /\left(A_{f t-1}+B_{f t-1}\right)<i_{f t-1} \text { or } \hat{y}_{f t-1} \geq \psi \cdot y_{f t-1}\end{cases}
$$

where $\alpha>0$ is a parameter representing the maximum percentage change of the relevant variable (in this case the target leverage), $U(0,1)$ is a random number picked from a uniform distribution in the interval $(0,1), \pi_{f t-1}$ is the gross profit (realized in the previous period), $A_{f t-1}+B_{f t-1}$ is the previous period total capital (net worth $A_{f t-1}$ plus debt $B_{f t-1}$ ), $i_{f t-1}$ is the nominal interest rate paid on previous debts, ${ }^{18} \hat{y}_{f t-1}$ represents inventories (that is, unsold goods), $0 \leq \psi \leq 1$ is a parameter representing a threshold for inventories based on previous period production $y_{f t-1}$.

The bank-specific component of the interest rate charged on loans to firms evolves as follows:

$$
\hat{i}_{b t}= \begin{cases}\hat{i}_{b t-1} \cdot(1-\alpha \cdot U(0,1)), & \text { if } \quad \hat{B}_{b t-1}>0 \\ \hat{i}_{b t-1} \cdot(1+\alpha \cdot U(0,1)), & \text { if } \quad \hat{B}_{b t-1}=0\end{cases}
$$

where $\hat{B}_{b t-1}$ is the amount of money that the bank did not manage to lend to firms in the previous period.

Labor market. In each period, workers post a wage $w_{i t}$ which is updated according to the following rule:

$$
w_{i t}= \begin{cases}w_{i t-1} \cdot(1+\alpha \cdot U(0,1)), & \text { if } i \text { employed at time } t-1 \\ w_{i t-1} \cdot(1-\alpha \cdot U(0,1)), & \text { if } i \text { unemployed at time } t-1\end{cases}
$$

However, the required wage has a minimum tied to the price of a single good.

Goods market. Households set their desired consumption as follows:

$$
c_{i t}^{d}=c_{1} \cdot w_{i t}+c_{2} \cdot A_{i t}
$$

where $0<c_{1} \leq 1$ is the propensity to consume current income, $0 \leq c_{2} \leq 1$ is the propensity to consume the wealth $A_{i t}$. If the amount $c_{i t}^{d}$ is smaller than the average price of one good $\bar{p}$ then $c_{i t}^{d}=\min \left(\bar{p}, w_{i t}+A_{i t}\right)$. 
Firms set the selling price according to this rule:

$$
p_{f t}= \begin{cases}p_{f t-1} \cdot(1+\alpha \cdot U(0,1)), & \text { if } \hat{y}_{f t-1}=0 \text { and } y_{f t-1}>0 \\ p_{f t-1} \cdot(1-\alpha \cdot U(0,1)), & \text { if } \hat{y}_{f t-1}>0 \text { or } y_{f t-1}=0\end{cases}
$$

However, the minimum level of the price is given by the average cost of production.

Deposit market. Banks offer an interest rate on deposits according to their funds requirement:

$$
i_{b t}^{D}= \begin{cases}i_{b t-1}^{D} \cdot(1-\alpha \cdot U(0,1)), & \text { if } \bar{k}_{b t}-B_{b t}-\Gamma_{b t}>0 \\ \min \left\{i_{b t-1}^{D} \cdot(1+\alpha \cdot U(0,1)), i_{C B t}\right\}, & \text { if } \bar{k}_{b t}-B_{b t}-\Gamma_{b t}=0\end{cases}
$$

where $\Gamma_{b t}$ is the amount of public debt bought by bank $b$ at time $t$.

Households set the minimum interest rate they want to obtain on bank deposits as follows:

$$
i_{i t}^{D}= \begin{cases}i_{i t-1}^{D} \cdot(1-\alpha \cdot U(0,1)), & \text { if } D_{i t-1}=0 \\ i_{i t-1}^{D} \cdot(1+\alpha \cdot U(0,1)), & \text { if } D_{i t-1}>0\end{cases}
$$

where $D_{i t-1}$ is the individual $i$ 's deposit in the previous period. 


\section{APPENDIX C: Parameter space and quasi-steady-state}

Table 2 reports the value of parameters we used to simulate the model. Model simulations are not calibrated against empirical data. We do not perform any validation exercise, but just analyze the qualitative behavior of the model both in the baseline scenario and for different configurations of regulatory parameters. However, for the chosen parameter setting, the model exhibits a statistical equilibrium around a quasi-steady-state. Moreover, multiple simulations and sensitivity analyses, as those proposed in the present paper to explore the effects of changing regulatory parameters, show that the model is quite robust to alternative parameter settings. In order to describe the statistical properties of the quasi-steady-state, we report the average and standard deviation of the main macroeconomic variables in Table 3 . In particular, simulation data are collected from 1000 runs of the same model (only changing the sequence of random numbers): in 995 simulations, the model exhibits a "regular behavior", that is the economy presents business cycle fluctuations, that does not exclude the presence of endogenous crises; however, only in 5 out of 1000 runs, an "extended crisis" scenario emerges, that is the economy may enter a long depression, recovering only in the very long run (in 3 out of 5 cases) or give rise to a complete crash of the private sector without recovery at all (in the remaining 2 cases).

Accordingly, we are able to reproduce the endogenous evolution of both small and large crises within the same agent-based macroeconomic framework. There are pros and cons of such a result. On the one hand, we are able to describe a variety of macroeconomic scenarios, including extended crises, without changing the parameter setting nor the agents' behavioral rules and/or the interaction mechanisms; in this way, we do not introduce ad hoc assumptions to obtain such results; moreover, the agents try to adapt to a changing environment according to their simple rules of behavior based on heterogeneous variables (e.g., a worker decreases her requested wage if unemployed, and vice versa). On the other hand, we assume that agents' behavioral rules are fixed, that is they are time-invariant, meaning that agents behave according to the same rules and the same parameters (for instance, during a boom or in a large crisis). Therefore, a possible extension of our model could consider that agents choose the rules to follow depending on the characteristics of the environment in which they are operating (e.g. an unemployed worker decreases her requested wage, not only taking into account her own occupational status as in Equation 12, but considering the overall level of unemployment rate as well) or that they can switch from one rule to another (e.g. from risk-prone to risk-averse behavior for an agent passing from a booming phase to a following recession) based on some performance indicator (e.g. expected profit). Moreover, different degrees of rationality embedded in agents' learning processes can be introduced, thus allowing to study the relationship between agents' rationality and macroeconomic performance, in particular when heterogeneous degrees of rationality are considered in the population of agents (see, for instance, Sinitskaya and Tesfatsion, 2015, in which they show that (i) simple rules of behavior 
Table 2: Parameter setting

\begin{tabular}{l|c|c}
\hline $\mathrm{H}$ & number of individuals & 500 \\
$\mathrm{~F}$ & number of firms & 80 \\
$\mathrm{~B}$ & number of banks & 10 \\
$\alpha$ & adjustment parameter & 0.05 \\
$\chi$ & matching imperfect information & 0.2 \\
$\psi$ & inventory threshold & 0.1 \\
$\gamma_{1}$ & max bank's leverage & 10 \\
$\gamma_{2}$ & max of bank's capital invested in lending & 0.5 \\
$\beta$ & max bank's lending to single firm & 0.1 \\
$\rho$ & risk premium on firm's loan & 2 \\
$c_{1}$ & propensity to consume current income & 0.8 \\
$c_{2}$ & propensity to consume wealth & 0.3 \\
$\phi$ & firm's productivity & 3 \\
$\tau$ & tax rate on income & 0.3 \\
$\tau^{\prime}$ & tax rate on wealth & 0.05 \\
$\bar{\tau}^{\prime}$ & threshold for tax on wealth & 3 \\
$g$ & \% of public workers on population & 0.33 \\
$i_{C B}$ & central bank policy rate & 0.01 \\
\hline \hline
\end{tabular}

can outperform more complicated rules as "adaptive dynamic programming", and that (ii) memory length allowing for some degree of adaptation is key for good performance). These are topics which are worth to be investigated. We may provide our contribution by extending the current framework along these lines in the next future. 
Table 3: Average values and standard deviations (computed over the time span 101-150) from 995 simulations of the baseline model with mean unemployment rate below $20 \%$.

\begin{tabular}{l|c|c}
\hline Variable & Mean & St. Dev. \\
\hline Unemployment rate & $9.92 \%$ & $1.63 \%$ \\
Unemployment volatility & $2.05 \%$ & $0.48 \%$ \\
Firm default rate & $6.45 \%$ & $2.10 \%$ \\
Bank default rate & $0.57 \%$ & $0.57 \%$ \\
Wage share & $63.4 \%$ & $0.53 \%$ \\
Public deficit & $3.26 \%$ & $0.19 \%$ \\
Interest rate & $9.11 \%$ & $1.93 \%$ \\
Inflation rate & $1.99 \%$ & $0.07 \%$ \\
Firm mean leverage & 1.65 & 0.24 \\
Bank mean exposure & 3.27 & 1.30 \\
\hline \hline
\end{tabular}

\section{APPENDIX D: Additional results from the sensitivity analysis}

In this appendix we provide a table in which the results of a Monte Carlo simulation including different combinations of regulatory parameters, already analyzed in Table 1 only regarding the unemployment rate, are presented. The average values across Monte Carlo simulations are reported in Table 4 . We also include Table 5, in which the median values of multiple simulations are reported, to assess the robustness of our findings.

Table 4: Summary of Monte Carlo simulations. In each column there is a parameter combination for which we perform 100 Monte Carlo repetitions on a time span of $T=500$. As in Table 1 we report the results for the simulations without large crises. Standard deviations are in brackets.

\begin{tabular}{|c|c|c|c|c|c|c|}
\hline & $\begin{array}{c}\beta=0.1 \\
\gamma_{1}=10 \\
\overline{\delta_{b}}=0\end{array}$ & $\begin{array}{c}\beta=0.5 \\
\gamma_{1}=10 \\
\overline{\delta_{b}}=0\end{array}$ & $\begin{array}{c}\beta=0.1 \\
\gamma_{1}=50 \\
\overline{\delta_{b}}=0\end{array}$ & $\begin{array}{c}\beta=0.5 \\
\gamma_{1}=50 \\
\overline{\delta_{b}}=0\end{array}$ & $\begin{array}{c}\beta=0.1 \\
\gamma_{1}=10 \\
\overline{\delta_{b}}=0.45\end{array}$ & $\begin{array}{l}\beta=0.5 \\
\gamma_{1}=50 \\
\overline{\delta_{b}}=0.45\end{array}$ \\
\hline Public deficit $\%$ & $3.16(0.05)$ & $3.17(0.15)$ & $3.16(0.26)$ & $3.13(0.01)$ & $3.26(0.13)$ & $3.33(0.54)$ \\
\hline Interest rate $\%$ & $8.04(0.81)$ & $9.05(5.76)$ & $7.43(0.69)$ & $7.79(0.21)$ & $10.06(0.99)$ & $10.81(4.27)$ \\
\hline Inflation rate $\%$ & $1.99(0.04)$ & $1.94(0.10)$ & $2.02(0.07)$ & $2.01(0.01)$ & $1.91(0.05)$ & $1.88(0.15)$ \\
\hline Firm default rate $\%$ & $6.21(0.70)$ & $7.96(5.49)$ & $6.12(4.59)$ & $5.88(0.29)$ & $8.57(7.72)$ & $9.14(7.27)$ \\
\hline Bank default rate $\%$ & $0.40(0.38)$ & $2.28(4.60)$ & $0.60(1.10)$ & $0.62(0.21)$ & $1.29(1.46)$ & $6.52(4.67)$ \\
\hline Firm leverage & $1.26(0.31)$ & $1.02(0.32)$ & $1.55(0.33)$ & $1.40(0.10)$ & $0.59(0.13)$ & $0.53(0.22)$ \\
\hline Bank exposure & $3.14(0.61)$ & $3.50(1.48)$ & $4.73(3.64)$ & $3.74(0.26)$ & $4.89(0.93)$ & $12.89(9.26)$ \\
\hline Corr(unemp.-firm leverage) \% & -6.37 & -3.19 & -22.44 & -23.55 & -36.26 & -28.82 \\
\hline Corr(unemp.-bank exposure) $\%$ & -47.36 & -44.49 & -41.91 & -47.11 & -20.74 & -2.56 \\
\hline
\end{tabular}


Table 5: Summary of Monte Carlo simulations. In each column there is a parameter combination for which we perform 100 Monte Carlo repetitions on a time span of $T=500$. As in Table 1 we report the results for the simulations without large crises: we compute the mean of the analyzed variables for each simulation and then we report the median across simulations.

\begin{tabular}{l|cccccc}
\hline & $\beta=0.1$ & $\beta=0.5$ & $\beta=0.1$ & $\beta=0.5$ & $\beta=0.1$ & $\beta=0.5$ \\
& $\gamma_{1}=10$ & $\gamma_{1}=10$ & $\gamma_{1}=50$ & $\gamma_{1}=50$ & $\gamma_{1}=10$ & $\gamma_{1}=50$ \\
& $\overline{\delta_{b}}=0$ & $\overline{\delta_{b}}=0$ & $\overline{\delta_{b}}=0$ & $\overline{\delta_{b}}=0$ & $\overline{\delta_{b}}=0.45$ & $\overline{\delta_{b}}=0.45$ \\
\hline Mean U \% & 9.40 & 9.93 & 8.66 & 9.27 & 11.07 & 11.03 \\
U volatility \% & 1.83 & 2.00 & 1.94 & 2.05 & 1.68 & 1.96 \\
Public deficit \% & 3.14 & 3.15 & 3.11 & 3.13 & 3.23 & 3.19 \\
Interest rate \% & 7.75 & 8.31 & 7.27 & 7.78 & 10.06 & 13.40 \\
Inflation rate \% & 2.01 & 1.98 & 2.04 & 2.01 & 1.92 & 1.92 \\
Firm default rate \% & 6.07 & 6.42 & 5.38 & 5.88 & 5.80 & 6.57 \\
Bank default rate \% & 0.22 & 0.99 & 0.30 & 0.60 & 0.69 & 4.22 \\
Firm leverage & 1.32 & 1.12 & 1.64 & 1.40 & 0.60 & 0.59 \\
Bank exposure & 3.24 & 3.24 & 4.27 & 3.73 & 4.60 & 10.40 \\
\hline \hline
\end{tabular}

